\title{
Review on cadmium removal from aqueous solutions
}

\author{
K.S. Rao ${ }^{1 *}$, M. Mohapatra ${ }^{1}$, S. Anand ${ }^{2}$, P. Venkateswarlu ${ }^{3}$ \\ ${ }^{1}$ Institute of Minerals and Materials Technology, Bhubaneswar 751 013, INDIA \\ ${ }^{2}$ Presently Murdoch University, Perth, WESTERN AUSTRALIA \\ ${ }^{3}$ Department of Chemical Engineering, College of Engineering, Andhra University, Visakhapatnam 530003, Andhra Pradesh, INDIA \\ "Corresponding Author: e-mail: srkaranam@yahoo.com
}

\begin{abstract}
Cadmium is known to be toxic for living organism even if it is present in low levels. Generally it is associated with zinc and copper minerals and is produced as a byproduct of these industries. It enters the environment from electroplating, smelting, alloy manufacturing, pigments, plastic, cadmium-nickel batteries, fertilizers, pesticides, mining, pigments and dyes, textile operations and refining industries. Various ways of cadmium removal are: precipitation, ion exchange, solvent extraction and adsorption. The present review specifically describes various types of adsorbents which have been used for removing cadmium from aqueous solutions. General emphasis has been on the utilization of agricultural, industrial wastes and low cost synthetic oxides as adsorbents. In most of the studies batch mode data has been evaluated by determining the kinetic, isothermic and thermodynamic parameters. A number of studies have also addressed the mechanism of adsorption process employing instrumental techniques such as XRD, FTIR, SEM etc. Modeling of column data has also been reported by some researchers. More attention needs to be given for regeneration/reuse/ safe disposal of the loaded adsorbents wherein the data are insufficient. The engineering aspects also need attention for commercial application of various adsorbents.
\end{abstract}

Key words: Cadmium, adsorption, agricultural wastes, industrial wastes, synthetic oxides, low grade ores/overburden.

\section{Introduction}

Cadmium occurs naturally in the environment by the gradual process of erosion and abrasion of rocks and soils, and from singular events such as forest fires and volcanic eruptions. It is therefore naturally present everywhere in air, water, soils and foodstuffs. The best known cadmium mineral is greenockite, cadmium sulfide $(77.6 \% \mathrm{Cd})$. Other minerals are otavite, cadmium carbonate $(61.5 \% \mathrm{Cd})$ and pure cadmium oxide $(87.5 \% \mathrm{Cd})$. Greenockite $(\mathrm{CdS})$ is nearly always associated with sphalerite $(\mathrm{ZnS})$. As a consequence, cadmium is produced mainly as a byproduct from mining, smelting, and refining of sulfide ores of zinc.

Cadmium is one of the heavy metals, which is highly toxic to human, plants and animals. The metal is of special concern because it is non-degradable and therefore persistent. The main anthropogenic pathway through which cadmium enters environment is via wastes from industrial processes such as electroplating, smelting, alloy manufacturing, pigments, plastic, cadmium-nickel batteries, fertilizers, pesticides, mining, pigments and dyes, textile operations and refining (Grayson and Othumer, 1978; Forstner and Wittman, 1981; Salim et al.,1992; Cheung et al., 2000; Wu et al, 2010). All over the world cadmium contaminated waste waters and effluents are being generated either directly due to Cd production or through secondary sources. A major past disaster 'Itai-Itai' due to contamination of cadmium in Jintsu river of Japan is well known. Various regulatory bodies have set the maximum limits for the discharge of toxic heavy metals in the aquatic systems. However, the metal ions that are being added to the water stream are at a much higher concentration than the prescribed limits by industrial activities, thus leading to the health hazards and environmental degradation. In order to solve heavy metal pollution in the environment, it is important to bring applicable solutions. Thus the treatment or purification of contaminated water and effluents is one of the major areas of active research. According to WHO's recommendation Cd(II) limit in drinking water is $0.005 \mathrm{mg} / \mathrm{L}$. The present paper reviews various techniques being followed and research efforts being made for removal of $\mathrm{Cd}(\mathrm{II})$ from aqueous solutions with a special emphasis on the adsorption technique. 


\section{Different techniques for cadmium remediation}

There are various physical and chemical methods used to treat mining and industrial effluents containing Cd(II). Those methods can be broadly divided into the following categories: chemical methods, membrane, ion exchange, solvent extraction and adsorption techniques.

\subsection{Chemical methods}

The chemical methods for cadmium remediation include precipitation and cementation techniques.

\subsubsection{Precipitation}

A variety of specialized treatment techniques for the removal of heavy metals prior to their discharge into the environment have been developed (Clifford et al., 1986). Among them, the simple precipitation of metals as insoluble hydroxides, carbonates, or sulfides is used in about $75 \%$ of electroplating facilities to treat wastewater (Karthikeyan et al., 1996). Of all the treatment techniques, heavy metal hydroxide precipitation is the most commonly employed because of its low cost and simplicity. This process is quite simple as the $\mathrm{pH}$ of the effluent is increased by using lime $(\mathrm{CaO})$ or caustic soda $(\mathrm{NaOH})$ to precipitate and hence immobilize the heavy metals as their respective hydroxides. US patent of Schlage Lock Company (1975) describes a process to remove cadmium from plating effluents by adding barium acetate. Rickelton (1998) found a selective method of removing cadmium by precipitation as its diisobutyldithiophosphinate complex. A three-step precipitation process has also been reported (Islamoglu et al., 2006) which included (a) acid treatment with nitric acid $\left(\mathrm{HNO}_{3}\right)$, cyano-metal complexes were decomposed in acidification step and complete removal of iron was achieved, (b) alkali precipitation by sodium hydroxide (NaOH), large portion of $\mathrm{Cd}$ was recovered as pure $\mathrm{Cd}(\mathrm{OH})_{2}$ and (c) as a polishing step sulfide precipitation by sodium sulfide $\left(\mathrm{Na}_{2} \mathrm{~S}\right)$ was applied. Cadmium can also be precipitated by addition of lime and magnesium (Lin et al., 2005)

\subsubsection{Cementation}

General reaction for cadmium cementation with other metal ions is represented by the Eq. (1)

$$
\mathrm{Cd}^{2+}+\mathrm{M}^{0}=\mathrm{M}^{2+}+\mathrm{Cd}^{0}
$$

where $\mathrm{M}$ is a bivalent metal.

$\mathrm{Ku}$ et al. (2002) reported that cadmium could be removed from solutions by cementation with zinc powder. The optimum $\mathrm{pH}$ found was 4-5. The reaction rate was approximately first order with respect to both the amount of zinc and the concentration of cadmium ion. Among the surfactants used in this study, only the presence of sodium dodecyl sulfonate, an anionic surfactant, noticeably enhanced the cementation rate of cadmium by zinc powder. The presence of ethylene-diaminetetraacetic acid (EDTA) in aqueous solutions inhibited the removal of cadmium by zinc due to the possible formation of Cd-EDTA chelates, which possess higher redox potential than that of free cadmium ions. Gould et al.'s report (1986) revealed that cadmium could be removed by cementation with magnesium. They reported that the order of kinetics depended on the initial concentration. It was half order up to $25 \mathrm{mM}$ (migration control mechanism) and first order (diffusion control) beyond $25 \mathrm{mM}$.

Younesi et al. (2006) studied cementation of cadmium ions by zinc powder in a batch reactor at low and high concentrations at pH 5.2-5.4 and it was shown that the reaction was first-order. XRD and SEM analysis confirmed that the deposited layer was metallic with no evidence of basic zinc sulphate or re-dissolution of cadmium. The experiments demonstrated that at initial cadmium concentrations of $>1000 \mathrm{mg} / \mathrm{L}$, the ash diffusion control model prevailed, while at concentrations $<500 \mathrm{mg} / \mathrm{L}$, the data had good agreement with the film diffusion model. For concentrations between $500 \mathrm{mg} / \mathrm{L}$ and $1000 \mathrm{mg} / \mathrm{L}$, a combination of ash diffusion and film diffusion models controlled the reaction rate. Statistical data analysis was performed and different reaction rate constants were estimated from the equations for high and low initial cadmium concentrations.

\subsection{Membrane separation technique}

Liquid membrane process incorporates a dispersed emulsion including organic membrane and aqueous internal phase in a continuous external phase $(\mathrm{W} / \mathrm{O} / \mathrm{W})$. The solute in the external phase penetrates through the membrane phase, in which carrier is added to solubilise otherwise insoluble solute in the membrane phase. The transferred solute by the carrier reacts with a stripping agent at the interface of the membrane and internal phases and will be trapped in internal phase. The emulsion phase is then broken in a demulsifier and the oil phase is recycled for reusing in the emulsification process. Various types of membrane processes are employed to remove cadmium from aqueous solutions such as liquid membrane, (Urtiaga et al., 2000) hollow fiber supported liquid membrane, (Breembroek et al., 1998) supported liquid membrane, (Swain et al., 2006) emulsion liquid membrane 
(Mortaheb et al., 2009). But these processes tend to suffer from the instability of the membranes in salty or acidic conditions and fouling by inorganic and organic substances present in wastewaters.

The use of the electro-dialysis technique for the treatment of a synthetic waste water containing approximately $0.0089 \mathrm{~mol} / \mathrm{L}$ cadmium and $0.081 \mathrm{~mol} / \mathrm{L}$ cyanide was studied using a five-compartment electro-dialysis cell (Marder et al., 2003). Electrolysis allows the removal of metal ions from the solution in a solid metallic form for recycling. The advantage of this method is that there is no need for additional chemicals, and hence, there is no sludge generation. However, it is inefficient at low metal concentration.

\subsection{Ion exchange technique}

Ion exchange operations are essentially chemical reactions between an electrolyte in solution and an insoluble electrolyte with which the solution is contacted. The ion exchange between heavy metal ion and hydrogen ion is shown in Eq. (2)

$$
\mathrm{M}^{2+}+2 \mathrm{RH}=\mathrm{R}_{2} \mathrm{M}+2 \mathrm{H}^{+}
$$

Where $\mathrm{M}$ is bivalent metal and $\mathrm{R}$ is the aliphatic portion of the cation exchanger. Mitchenko et al. (1998) studied the removal of mercury, cadmium, calcium, copper, nickel and zinc with modified commercial VP-l AP polyvinylpyridine resins with 1,3-dichlor5-dimethyl hydantoin. Cadmium(II) adsorption from aqueous sulphate medium on Lewatit TP260 cationic (di-Na ${ }^{+}$) ion exchange resin was investigated (Alguacil 2003). It was reported that cadmium(II) adsorption on the resin was governed by the Langmuir equation, whereas cadmium(II) uptake was particle diffusion controlled. The moving boundary particle diffusion model fitted the initial metal adsorption on the resin. The adsorptivity of $\mathrm{N}_{5} \mathrm{O}_{3}(\mathrm{~N}, \mathrm{~N}$-di(sec-octyl) acetamide) levextrel resin to cadmium in $\mathrm{HBr}$ and $\mathrm{NaBr}-\mathrm{H}_{2} \mathrm{SO}_{4}$ media has been studied (Chen et al., 1998). The results showed that the adsorption of the $\mathrm{N}_{5} \mathrm{O}_{3}$ levextrel resin to cadmium was carried out in pseudo-first-order reaction and followed Freundlich isothermal adsorption equation. Many researchers (Ahmed et al., 1998; Blokhin and Taushkanov, 1994; Koivula et al., 2000; Malla et al., 2002; Dabrowski et al., 2004; Wang and Fthenakis 2005; Pehlivan and Altun, 2006; Kocaoba , 2007) studied cadmium removal using different resins such as Amberlite IR 120 (Kocaoba , 2007), dolamite (Kocaoba , 2007), Dowex $50 \mathrm{~W}$ (Pehlivan and Altun , 2006), Amberlite IRC 718 (Malla et al., 2002) etc. Ion exchange usually requires a high capital cost equipments as well as high operational cost due to the use of chemicals for resin regeneration. Hence it is not a popular method for $\mathrm{Cd}(\mathrm{II})$ remediation from wastewaters.

\subsection{Solvent extraction technique}

Solvent extraction is a powerful technique used mainly for recovering /separating metal ions from aqueous solutions having higher concentrations to obtain high pure solutions. The principle of solvent extraction is that when a metal ion solution is contacted with a solvent, the metal ion is distributed between the two phases. Liquid-liquid extraction from aqueous media by using specific extractants is also applied for separation of cadmium (Nogueira and Delmas., 1999; Gupta et al., 2001; Takeshita et al., 2003; Jia et al., 2004; Takeshita et al., 2004). Reddy et al. (2006) reported the use of different solvents (TOPS 99, Cyanex 923, Cyanex 272, Cyanex 302 and Cyanex 301) diluted in kerosene to remove cadmium from sulphate solutions. Complete process flow sheet for the separation and recovery of $\mathrm{Cd}(\mathrm{II}), \mathrm{Co}(\mathrm{II})$ and $\mathrm{Ni}(\mathrm{II})$ was proposed. The extraction of cadmium and zinc from thiocyanate solutions with bis-2-ethylhexyl sulphoxide (EHSO) in benzene has also been studied (Reddy et al., 1996). Carboxylic acids have also been used to remove cadmium (Preston., 1994).

The disadvantage of this method is that the large amount of solvent of the extracted phase should be refreshed in a costly stripping step. It may not be advisable to adopt this technique to remove heavy metals whose concentration is very less as the recovery cost will be very high.

Some of the data on cadmium removal using various techniques described above are given in Table1. It is observed that the both precipitation and solvent extraction give removal efficiencies as high as $99 \%$. Usually the precipitation reactions are very fast and the rates are not measured. In case of solvent extraction the contact time for organic and aqueous phases are only a few minutes and this separation technique is governed more through the distribution co-efficient for efficient separation. High cost of solvents coupled with solvent losses during continuous operations remains to be a costly affair especially for water treatment. The efficiency of membranes depend on the nature of membrane as mentioned in Table1. Cadmium removal from solutions containing other bivalent metals like zinc, nickel or cobalt using carrier solvents such as TOPS 99 and D2EHPA+TRPO is > 98.5 whereas Cyanex 923 is much less efficient (85.8\% removal). Some of the ion exchange resins like Amberlite IRC-718, Amberlite IR-120 are extremely efficient for cadmium zinc separation when compared to Dowex $50 \mathrm{~W}$ or S-950. But it remains a fact that this technique is more relevant for separation of cadmium from multi cation containing solutions rather than for remediation of $\mathrm{Cd}(\mathrm{II})$ for treatment of waste waters.

\subsection{Adsorption technique}

Conventional techniques have their own inherent limitations such as less efficiency, sensitive operating conditions, production of secondary sludges and costly for their disposal (Maran and Protton, 1971). Another powerful technique for heavy and toxic ions 
remediation is adsorption. The adsorption process has many advantages such as: low cost of adsorbent, easy availability, utilization of industrial, biological and domestic waste as adsorbents, low operational cost, ease of operation compared to other processes, reuse of adsorbent after regeneration, capacity of removing heavy metal ions over wide range of $\mathrm{pH}$ and to a much lower level, ability to remove complex form of metals that is generally not possibly by other methods, environmentally friendly, cost effective and technically feasible alternative due to utilization of biomaterials.

Table 1 Comparison of cadmium removal data using different techniques

\begin{tabular}{|c|c|c|c|c|}
\hline \multirow[t]{2}{*}{ Technique } & \multirow{2}{*}{$\begin{array}{l}\text { Kinetics order / } \\
\text { \%Recovery }\end{array}$} & \multicolumn{2}{|c|}{ Cd Concentration } & \multirow[t]{2}{*}{ Reference } \\
\hline & & Initial & Final & \\
\hline \multicolumn{5}{|l|}{ Precipitation } \\
\hline Aerophine 3481A & $99.7 \%$ & $18 \mathrm{mg} / \mathrm{L}$ & $0.05 \mathrm{mg} / \mathrm{L}$ & Rickelton, 1998 \\
\hline $\mathrm{Na}_{2} \mathrm{~S}$ & $99.9 \%$ & $7500 \mathrm{mg} / \mathrm{L}$ & $10 \mathrm{mg} / \mathrm{L}$ & Islamoglu et al., 2006 \\
\hline lime $/ \mathrm{Mg}(\mathrm{OH})_{2}$ & $\sim 100 \%$ & $1 \mathrm{mM}$ & nil & Lin et al., 2005 \\
\hline Electro coagulation & $>99 \%$ & $50-250 \mathrm{mg} / \mathrm{L}$ & & Bazrafshan et al., 2006 \\
\hline \multicolumn{5}{|l|}{ Cementation } \\
\hline Zinc powder & $1^{\text {st }}$ Order & $<500 \mathrm{mg} / \mathrm{L}$ & & Ku et al., 2002 \\
\hline Zinc powder & $1^{\text {st }}$ Order & & & Younesi et al., 2006 \\
\hline Magnesium & $1 / 2$ Order & $<25 \mathrm{mM}$ & & Gould et al., 1986 \\
\hline Magnesium & $1^{\text {st }}$ Order & $>25 \mathrm{mM}$ & & Gould et al., 1986 \\
\hline Zinc powder + SDS & $95.6 \%$ & $6.5 \mu \mathrm{g} / \mathrm{L}$ & $0.28 \mu \mathrm{g} / \mathrm{L}$ & Taha and Ghani, 2004 \\
\hline \multicolumn{5}{|l|}{ Membrane Separation } \\
\hline TOPS 99 & $99 \%$ & $0.89 \mathrm{mM}$ & & Swain et al., 2006 \\
\hline D2EHPA+TRPO & $98.6 \%$ & $0.18 \mathrm{mM}$ & $2.5 \mu \mathrm{M}$ & He et al., 2007 \\
\hline Cyannex 923 & $85.8 \%$ & $0.89 \mathrm{mM}$ & $0.13 \mathrm{mM}$ & Alguacil and Navarro, 2001 \\
\hline \multicolumn{5}{|l|}{ Ion Exchange } \\
\hline Amberlite IRC-718 & $99.5 \%$ & $20 \mathrm{mg} / \mathrm{L}$ & $0.1 \mathrm{mg} / \mathrm{L}$ & Fernandez, 2005 \\
\hline Resin A & $91 \%$ & $1060 \mathrm{mg} / \mathrm{L}$ & $96.46 \mathrm{mg} / \mathrm{L}$ & Wang and Fthenakis, 2005 \\
\hline Na-Amberlite IR 120 & $93.4 \%$ & $20 \mathrm{mg} / \mathrm{L}$ & $1.32 \mathrm{mg} / \mathrm{L}$ & Kocaoba and Akcin, 2005 \\
\hline S-950 & $83.9 \%$ & $1 \mathrm{mM}$ & $0.16 \mathrm{mM}$ & Koivula et al., 2000 \\
\hline Dowex 50W & $97 \%$ & $5 \mathrm{mM}$ & $0.15 \mathrm{mM}$ & Pehlivan and Altun, 2006 \\
\hline Amberlite IRC-718 & $\sim 100 \%$ & $0.25 \mathrm{mg} / \mathrm{L}$ & nil & Malla et al., 2002 \\
\hline Amberlite IR 120 & 97.4 & $20 \mathrm{mg} / \mathrm{L}$ & $0.52 \mathrm{mg} / \mathrm{L}$ & Kocaoba , 2007 \\
\hline \multicolumn{5}{|l|}{ Solvent Extraction } \\
\hline 1M D2EHPA & $99.7 \%$ & $30 \mathrm{~g} / \mathrm{L}$ & $0.09 \mathrm{~g} / \mathrm{L}$ & Nogueira and Delmas., 1999 \\
\hline $0.15 \mathrm{M}$ D2EHPA & $\sim 100 \%$ & $4.45 \mathrm{mM}$ & nil & Kumar et al., 2009 \\
\hline $\mathrm{D}_{2}$ EHDTPA & $99.1 \%$ & $1 \mathrm{~g} / \mathrm{L}$ & $<2 \mu \mathrm{g} / \mathrm{L}$ & Touati et al.,2009 \\
\hline $0.2 \mathrm{M}$ Cyanex 923 & $98 \pm 1 \%$ & $1 \mathrm{mM}$ & & Gupta et al., 2001 \\
\hline D2EHPA+TPEN & $>99 \%$ & $0.89 \mathrm{mM}$ & & Takeshita et al., 2003 \\
\hline $20 \%$ TBP & $99.9 \%$ & $0.5 \mathrm{mM}$ & & Mellah and Benachour,2007 \\
\hline Cyanex 301 & & $2.4 \mathrm{~g} / \mathrm{L}$ & $2.4 \mathrm{mg} / \mathrm{L}$ & Reddy et al., 2006 \\
\hline
\end{tabular}

The last few decades have witnessed tremendous interest in development of new adsorbents and to modify the performance of existing ones. The activated carbon is being used widely to treat wastewater to remove organic or inorganic pollutants because of their large specific surface area, high adsorption capacity and special surface chemical properties (Dubinin, 1975; Park and Kim, 1999). The other adsorbents are: synthetic metal oxides especially iron oxides/hydroxides, aluminum oxides/hydroxides, mixed $\mathrm{Fe}-\mathrm{Al}$ oxides and doped oxides. In order to develop low-cost adsorbents a number of low/off grade ores and industrial wastes have been tested for their cation/anion uptake behaviour. In a similar way agricultural wastes have been extensively tested for wastewater/effluent treatment. These adsorbents are discussed in separate sections.

\subsubsection{Activated carbon}

The physical and chemical properties of activated carbon depend on pore size, pore distribution and number of surface oxygen groups. The pore size and pore volume can be controlled during the activation process such as activation time, activation agent and temperature. The surface oxygen also can be manipulated by using suitable oxidizing agents and thermal treatment in order to get the surface functional groups such as carboxyl, phenolic and lactonic group attached to carbon (Toles et al., 1999; Park and Jang 2002). These groups can improve the adsorption capacity and selectivity on a certain adsorbate in the gaseous or liquid phase (Barton et al., 1997; Pradhan and Sandle, 1999). 
Activated carbon was used to remove cadmium ions from wastewater. The activated carbon prepared from various raw materials having high carbonaceous materials, including wood, saw dust, coconut shell, coir pith, nut shells, almond shells, peanut husks (Rao et al., 2006; Cheung et al., 2001; Ricordel et al., 2001; Ferro-García et al., 1988) etc. has been used for Cd(II) removal. These can be activated by thermal decomposition in a high temperature oxidation or low temperature chemical dehydration reaction. These activated carbons were modified to improve the adsorption capacity by various methods such as treating with sulfur (Gomez-serrano et al., 1998), sulfur dioxide (Macías-García et al., 2003), surfactant (Nadeem et al., 2009) and electrochemical oxidation (Rangel-Mendez et al., 2000). Activation was also carried out using $\mathrm{ZnCl}_{2}$ (Kula et al., 2008). Kadiravelu and Namasivayam (2003) used activated carbon prepared from coconut coir pith. Mohan and Singh (2002) used activated carbon derived from bagasse. Their studies revealed that the uptake of cadmium is more than that of zinc and the adsorption occurred through film diffusion mechanism. The various experimental parameters studied for optimizing uptake capacity included contact time, adsorbate concentration, adsorbent dosage, $\mathrm{pH}$ and temperature.

\subsubsection{Synthetic, naturally occurring and waste oxidic materials as adsorbents}

\subsubsection{1 . Synthetic iron oxides:}

Iron oxides/hydroxides/oxyhydroxides form an important category of low-cost adsorbents for removal of heavy metals and organic compounds form wastewater (Fendorf et al., 1997; Heijman et al., 1999; Venema et al., 1998; Sen et al., 2002; O'reilly and Hochella Jr., 2003). Goethite, $\alpha-\mathrm{FeOOH}$, one of the most important iron oxyhydroxide, having double bonds of $\mathrm{FeO}(\mathrm{OH})$ octahedra which share edges and corners to form 2 by 1 octahedra tunnels partially bonded by $\mathrm{H}$ bonds (Schwertmann and Cornell, 1991; Cornell and Schwertmann, 1996), possesses the capability of incorporating a range of environmentally important oxy-anions and cations in its complex matrix. Hence, it can be used as an adsorbent. Coughlin and Stone studied the non reversible adsorption of divalent metal ion ( $\mathrm{Mn}, \mathrm{Co}, \mathrm{Ni}, \mathrm{Cu}$ and $\mathrm{Pb}$ ) onto goethite (Coughlin and Stone, 1995). Effect of $\mathrm{pH}$, temperature, and concentration on adsorption of cadmium on goethite has been reported by Johnson (1990). Christophi and Axe (1999) studied the competition of $\mathrm{Cd}, \mathrm{Cu}$ and $\mathrm{Pb}$ adsorption on goethite. Mohapatra and Anand synthesized goethite (Mohapatra and Anand, 2006) under controlled conditions and studied kinetic and thermodynamic aspects of cadmium adsorption. In another publication (Mustafa et al., 2004), synthetic goethite prepared by ageing a ferric hydroxide gel at high $\mathrm{pH}$ and room temperature was used for Cd adsorption and desorption studies in presence of sodium and calcium ions. Forbes et al. (1976) synthesized goethite to study adsorption of $\mathrm{Cd}, \mathrm{Co}, \mathrm{Cu}, \mathrm{Pb}$ and $\mathrm{Zn}$. Amorphous iron oxide was used by Benjamin and Leckie (1981). Improved adsorption capacities could be achieved by modifying goethite either by pre-treating or by doping with other metal ions. Phosphate pretreated goethite enhanced metal ion adsorption (Venema et al., 1997; Collins et al., 1999; Wang and Xing, 2002). With the increase of phosphate, higher $\mathrm{Zn}$ adsorption (Jie et al., 2000) has been reported. Depending on the way goethite was pretreated with oxalic acid, affinity for Cd(II) varied (Zhang et al., 2001). Mamata et al. (2009a) succeeded in doping synthetic goethite with $\mathrm{Mg}(\mathrm{II})$ and studied its effectiveness in removing cations. The experimental parameters such as time, $\mathrm{pH}$, concentration of adsorbate and adsorbent, temperature etc were varied for evaluation of goethite as an adsorbent.

Ferrihydrite $\left(\mathrm{Fe}_{5} \mathrm{HO}_{8} \cdot 4 \mathrm{H}_{2} \mathrm{O}\right)$, a poorly crystalline metastable mineral is a precursor to the more stable iron oxides such as goethite and hematite. It is typically described as 2- or 6- line ferrihydrite based on the number of peaks observed in the powder X-ray diffraction pattern. It is commonly formed by rapid oxidation of $\mathrm{Fe}(\mathrm{II})$-containing solutions followed by hydrolysis in the presence of crystallization inhibitors (Schwertmann, 1988). One of the most significant roles of ferrihydrite is as an adsorbent for various trace elements due to its coordination-unsaturated surface sites and large surface area. Some of the early work relating to the adsorption of cations and anions on ferrihydrite is summarized by Schwertmann and Taylor (1977) and Dzombak and Morel (1990). Uptake of $\mathrm{Cd}$ and $\mathrm{Cu}$ by sand sediments to which organic matter and ferrihydrite were added was investigated at $\mathrm{pH} 6.5$ by Warren et al. (1995). Mamata et al. (2010a) have studied the cation adsorption behaviour on 6-line ferrihydrite for $\mathrm{Pb}(\mathrm{II}), \mathrm{Cd}(\mathrm{II})$ and $\mathrm{Cu}(\mathrm{II})$.

Akaganeite $\beta-\mathrm{FeO}(\mathrm{OH})$, another important oxyhydroxide of iron finds applications in many fields due to its unique adsorption, ion exchange, and catalytic properties (Mazeina et al., 2006). Studies have been reported for the removal of cadmium, arsenic and hexavalent chromium from aqueous solutions using akaganeite (Deliyanni et al., 2003; Deliyanni and Matis, 2005; Lazaridis et al., 2005). Mamata et al. (2010b) synthesized high surface area $\left(176.16 \mathrm{~m}^{2} / \mathrm{g}\right)$ nano akaganeite $(\beta-\mathrm{FeOOH})$ powder using $1 \mathrm{M}$ ferric chloride solution, 0.2M EDTA solution as the chelating agent and ammonia for neutralization. The chemical, XRD, FTIR and Raman analysis confirmed the sample to be akaganeite. The TEM studies showed formation of mono phase cigar shaped akaganeite nano rods of 15 to $20 \mathrm{~nm}$ width with 80 to $100 \mathrm{~nm}$ length. Adsorption behaviour of $\mathrm{Pb}$ (II), $\mathrm{Cd}(\mathrm{II}), \mathrm{Cu}$ (II) and $\mathrm{Co}$ (II) from aqueous solutions onto nano akaganeite powder was studied. Various experimental parameters taken up to generate data included solution $\mathrm{pH}$, contact time, temperature, concentrations of adsorbate and adsorbent. With the increase in $\mathrm{pH}$ from 2 to 5 , uptake of metal ions increased. The adsorption kinetics followed pseudo-second order model. Both Langmuir and Freundlich models fitted well to the isothermic data of all the four cations. High loading capacities of $\sim 136,50,68$, and $87.7 \mathrm{mg} / \mathrm{g}$ were obtained for $\mathrm{Pb}(\mathrm{II}), \mathrm{Cd}(\mathrm{II}), \mathrm{Co}(\mathrm{II})$ and $\mathrm{Cu}(\mathrm{II})$ respectively. The XRD patterns of metal ion loaded samples, in general showed positive shifts for different planes of akaganeite. 


\subsubsection{Synthetic aluminum oxides}

Sen and Sarzali (2008) used synthetic $\mathrm{Al}_{2} \mathrm{O}_{3}$ (Merck) to find out its adsorption capacity for the removal of cadmium from solutions. Kinetic experiments clearly indicated that adsorption of cadmium metal ion $\left(\mathrm{Cd}^{2+}\right)$ on aluminum oxide was a two steps process: a very rapid adsorption of cadmium metal ion to the external surface is followed by possible slow intra-particle diffusion in the interior of the adsorbent. Overall the cadmium adsorption process followed pseudo-second-order kinetics. Bell and Saunders (2005) studied the effect of polyelectrolytes on the adsorption of cadmium with aluminum(III) oxide. It was found that the addition of millimolar concentrations of polyelectrolyte increased the removal of Cd ions from a $29.7 \mu \mathrm{M}$ aqueous solution by aluminum flocs from $40 \%$ to $75 \%$. Mixed oxides of iron and aluminum were used by Srivastava et al. (1998) to study the adsorption behaviour of cadmium.

\subsubsection{Synthetic manganese oxides}

Manganese oxides/hydroxides are known to be good scavengers for toxic metal ions. Cornelis and Weijden (1976) carried out experiments on the uptake of zinc and cadmium by manganese oxides. These experiments were carried out using synthetic hydrous Mn oxides in an ionic medium at $\mathrm{pH} 3.5$ and 4.0. A slight preference for uptake of $\mathrm{Cd}$ (II) over $\mathrm{Zn}$ (II) was observed. Cadmium removal from aqueous solutions by hydrous manganese dioxide has been studied by Mishra and Tiwary (1998) and Tripathy et al. (2006). Zaman et al. (2009) investigated the effect of phosphate complexation on $\mathrm{Cd}(\mathrm{II})$ adsorption by manganese dioxide $\left(\beta-\mathrm{MnO}_{2}\right)$. They investigated the adsorption properties of manganese dioxide in the presence of phosphate which is thought to be one of the most important complex forming species. The surface area, point of zero charge and structural morphology of the solid manganese dioxide were determined. $\mathrm{Cd}$ (II) adsorption studies were carried out on manganese dioxide as a function of $\mathrm{pH}$, temperature and phosphate concentration. $\mathrm{Cd}(\mathrm{II})$ adsorption increased with increasing $\mathrm{pH}$, temperature and phosphate concentration. It was found that phosphate formed both outer and inner sphere complexes via metal and ligand-like adsorption. The Langmuir equation was applied to describe the data and from the constants of this equation different thermodynamic parameters such as $\Delta H^{0}, \Delta S^{0}$ and $\Delta G^{0}$ were evaluated. Tonkin et al. (2004) modeled adsorption of divalent metal cations on hydrous manganese oxide using the diffuse double layer model.

\subsubsection{Oxide minerals, wastes, sludges and residues}

A number of low grade ores containing oxide minerals, sludges and residues have been used to treat $\mathrm{Cd}(\mathrm{II})$ contaminated water. Mining waste like chromite overburden has been reported (Mohapatra and Anand, 2006; Mohapatra and Anand, 2007a) to be a good adsorbent for $\mathrm{Cd}(\mathrm{II})$. Maximum loading capacity obtained was $19 \mathrm{mg} \mathrm{Cd} / \mathrm{g}$ of adsorbent. The authors reported thermodynamic parameters of enthalpy, entropy and free energy. Adsorption studies were carried out using Palygorskite (Ayuso and Sanchez, 2007). Palygorskite is a hydrated magnesium silicate mineral with fibrous morphology, and with a structure consisting of parallel ribbons of 2:1 layers. Column studies revealed that maximum cadmium adsorption obtained was $4.54 \mathrm{mg} / \mathrm{g}$. Cadmium adsorption with Perlite, naturally occurring glassy volcanic silicious rock was reported by Mathialagan and Viraraghavan (2002). Studies were conducted both by batch and column and optimum conditions established were: pH 6 and contact time $6 \mathrm{~h}$. Their data was best described by Ho's pseudo second order model for kinetics and Freundlich isotherm for equilibrium. Thomas model was used to describe the adsorption data from column studies. Kandah (2004) studied zinc and cadmium adsorption with low grade phosphate. Bhatnagar and Minocha's (2009) work was related to use of electroplating sludge. They successfully removed cadmium from waste waters and safely immobilized it in cement. Lateritic ore of Orissa was also tried to find out its suitability as adsorbent for cadmium removal by Mohapatra and Anand (2007b). Rout et al. (2009a) studied lead, cadmium and zinc adsorption with low grade bauxite and manganese ore (2009b). Lo and Lin (1989) reported the removal of heavy metal with activated sludge. A detailed study on adsorption of $\mathrm{Pb}(\mathrm{II})$ and $\mathrm{Cd}(\mathrm{II})$ on iron ore slimes (which is a waste material of steel industry) has been recently reported (Mohapatra et al., 2009b). Besides studying the adsorption behaviour, the authors had characterized the metal loaded adsorbent by carrying out XRD and EPMA studies.

Xue et al. (2009) were interested in finding the suitability of basic oxygen furnace (BOF) slag to remove cadmium, lead, copper and zinc from waste waters. The BOF slag used during the studies contained heterogeneous oxide materials which are compounded by some main oxides such as $\mathrm{CaO}, \mathrm{Fe}_{2} \mathrm{O}_{3}, \mathrm{SiO}_{2}, \mathrm{Al}_{2} \mathrm{O}_{3}$, and $\mathrm{MgO}$. The value of $\mathrm{pH}_{50}$ (the $\mathrm{pH}$ at which $50 \%$ adsorption occurs) was found to follow the sequence $\mathrm{Zn}(\mathrm{II})>\mathrm{Cu}(\mathrm{II})>\mathrm{Pb}$ (II) $>\mathrm{Cd}$ (II) in single-element systems, but $\mathrm{Pb}(\mathrm{II})>\mathrm{Cu}(\mathrm{II})>\mathrm{Zn}(\mathrm{II})>\mathrm{Cd}$ (II) in the multi-element system. The adsorption and potentiometric titrations data for various slagmetal systems were modeled using an extended constant-capacitance surface complexation model that assumed an ion-exchange process below $\mathrm{pH} 6.5$ and the formation of inner-sphere surface complexes at higher $\mathrm{pH}$. Inner-sphere complexation was more dominant for the $\mathrm{Cu}(\mathrm{II}), \mathrm{Pb}(\mathrm{II})$ and $\mathrm{Zn}(\mathrm{II})$ systems.

$\mathrm{Yu}$ et al. (2006) studied the kinetics of cadmium adsorption with aluminum precipitation products formed under the influence of tannate. NALCO plant sand waste containing silica, iron oxides and aluminum oxides (Mohapatra et al., 2009c) was utilized to remove $\mathrm{Cd}, \mathrm{Pb}$ and $\mathrm{Zn}$. The XRD pattern and FTIR spectra showed goethite, alumina and silica as the major phases present in Nalco plant sand. Effects of various parameters such as time, $\mathrm{pH}$, temperature, metal ions and adsorbent concentrations were studied. The data was fitted to various kinetic, thermodynamic and isothermic models. The XRD patterns of $\mathrm{Pb}$ (II) adsorbed Plant Sand sample showed that the crystallinity of silica phase was affected with the appearance of (110) plane and disappearance of (011) plane. It also disturbed the (110) plane of goethite. Cd(II) adsorbed sample showed disappearance of (011) plane of silica 
phase and transformation of alumina phase $\mathrm{Al}_{2} \mathrm{O}_{3}$ to $\sigma-\mathrm{Al}_{2} \mathrm{O}_{3}$. The adsorption of $\mathrm{Zn}$ (II) showed prominence of (110) plane of goethite with disappearance of $\sigma-\mathrm{Al}_{2} \mathrm{O}_{3}$ phase.

Manganese nodule residue was examined as potential adsorbent (Agrawal and Sahu, 2006; Mohapatra et al., 2008) to remove cadmium. The metal loaded adsorbent (Agrawal and Sahu, 2006) was subjected to desorption using different mineral acids and leaching by using toxicity characteristic leaching procedure (TCLP), synthetic precipitation leaching procedure (SPLP) tests for its further treatment or its safe disposal.

Clay Minerals (kaolinite, illite, montmorillonite) have also been reported to be good adsorbents. These are hydrous aluminum phyllosilicates, sometimes with variable amounts of iron, magnesium, alkali metals, alkaline earths and other cations. Clays have structures similar to the micas and therefore form flat hexagonal sheets. Clay minerals are common weathering products (including weathering of feldspar) and low temperature hydrothermal alteration products. Farrah and Fickering (1977) studied adsorption of lead and cadmium by clay minerals (kaolinite, illite and montmorillonite). Their studies revealed that in absence of ligands, metal ion adsorption increased with increasing $\mathrm{pH}$ whereas in presence of ligand the threshold $\mathrm{pH}$ changed to higher value, the magnitude of the effect was dependant on the stability of the metal complex formed. Extensive studies have been reported on Cd(II) adsorption on a number of Ontario soils (Bolton and Evans, 1996).

Suraj et al. (1998) studied the adsorption of cadmium and copper with crystalline kaolinite of Kerala after conversion into amorphous form and acid activation. When the substituted metal ion has a lower charge the net negative charge at the site enables adsorption of cations. Additional $-\mathrm{Al}-\mathrm{OH}$ and $-\mathrm{Si}-\mathrm{OH}$ bonds formed would also act as cation exchange centers. The exchangeability was found to decrease with an increase in the calcination temperature (to $600^{\circ} \mathrm{C}$ ) of kaolinite samples; i.e., from 6.34 to $3.08(\mathrm{Cd})$ and from 6.06 to $3.06(\mathrm{Cu}) \mathrm{mmol} / \mathrm{kg}$. An improved exchange kinetics applied for their modified (calcined and acid activated) counterparts, i.e., $13.36(\mathrm{Cd})$ and $18.80(\mathrm{Cu}) \mathrm{mmol} / \mathrm{kg}$. Cadmium adsorption with kaolinite has also been studied by a number of other researchers (Schindler et al., 1987; Puls and Bohn, 1988; Angove et al., 1997; Lackovic et al., 2003).

De-ming et al. (2007) studied lead and cadmium adsorption onto iron oxides and manganese oxides in the natural surface coatings collected on natural substances in the Songhua River of China. Studies on the adsorption of cadmium on hydrous iron(III) oxides in oxic sediments and waste $\mathrm{Fe}(\mathrm{III}) / \mathrm{Cr}(\mathrm{III})$ hydroxide have also been reported (Petersen et al., 1994; Namasivayam and Ranganathan , 1995). Oh et al. (2009) studied the single- and bi-solute competitive adsorptions of $\mathrm{Pb}(\mathrm{II})$ and $\mathrm{Cd}(\mathrm{II})$ onto sediments. In single-solute adsorption, Khan model fitted better than the other models such as Freundlich, Langmuir, DubininRadushkevich, Sips, Redlich-Peterson and Kargi-Ozmıhcı models. In bi-solute adsorption, competition between the solutes reduced the adsorbed amount of each solute compared with that in the single-solute system. Langmuir model parameters for single-solute and bi-solute competitive adsorptions were compared. In all sediments, maximum adsorption capacity of $\mathrm{Pb}$ (II) was higher than that of $\mathrm{Cd}(\mathrm{II})$, and the presence of both metals reduced the tendency to be adsorbed although Cd(II) adsorption was more affected than $\mathrm{Pb}(\mathrm{II})$. Hizal and Apak (2006) studied cadmium adsorption on kaolinite-based clays in the absence and presence of humic acid and modeled with the aid of the FITEQL 3.2 computer program using a modified Langmuir approach for capacity calculations.

Apak et al. (1998) reported that the toxic heavy metals, i.e. copper (II), lead (II) and cadmium (II), can be removed from water by metallurgical solid wastes, i.e. bauxite waste red muds and coal fly ashes acting as adsorbents. Both adsorption studies and column studies were carried out to optimize the adsorption process. The adsorption data were analyzed and fitted to linearised adsorption isotherms. Granular red mud (GRM) was evaluated for its potential to remove cadmium ions from aqueous solutions as a low-cost adsorbent (Zhu et al., 2007). Kinetics data at initial pH 6.0 and 3.0 were fitted to pseudo-second-order model. The maximum adsorption capacities for GRM observed in the experiments were determined as $38.2 \mathrm{mg} / \mathrm{g}$ at $20^{\circ} \mathrm{C}, 43.4 \mathrm{mg} / \mathrm{g}$ at $30^{\circ} \mathrm{C}$ and $52.1 \mathrm{mg} / \mathrm{g}$ at $40^{\circ} \mathrm{C}$. The feasibility of red mud (RM) was assessed for wastewater treatment using batch method by Lopez et al. (1998). The aggregates were prepared using red mud and $8 \%(\mathrm{w} / \mathrm{w}) \mathrm{CaSO}_{4}$ and examined their potential by batch and column experiments. The RM aggregates showed maximum adsorption capacities for $\mathrm{Cu}(\mathrm{II}), \mathrm{Zn}(\mathrm{II}), \mathrm{Ni}(\mathrm{II})$ and $\mathrm{Cd}(\mathrm{II})$ of $19.72,12.59$, 10.95 and $10.57 \mathrm{mg} / \mathrm{g}$, respectively with contact time of $48 \mathrm{~h}$. Some authors also examined red mud for the removal of cadmium and zinc from aqueous solutions (Gupta and Sharma, 2002). The removal of $\mathrm{Cd}(\mathrm{II})$ and $\mathrm{Zn}$ (II) was almost complete at low concentrations. Adsorption experiments of heavy metal ions i.e., $\mathrm{Pb}(\mathrm{II}), \mathrm{Cu}(\mathrm{II}), \mathrm{Cd}(\mathrm{II})$ in aqueous solutions by the pellet-type red mud adsorbents (Han et al., 2002) were studied under various experimental conditions. It was found that the pellets made from a mixture of $58.7 \mathrm{wt} \%$ red mud, $25.2 \mathrm{wt} \%$ kaolin, $11.7 \mathrm{wt} \%$ sodium silicate solution, $2.9 \mathrm{wt} \%$ fly ash, and $1.5 \mathrm{wt} \% \mathrm{magnesium}$ chloride at $600^{\circ} \mathrm{C}$ exhibited the highest removal efficiency of the heavy metal ions. Red mud has also been studied as a potential adsorbent for the removal of toxic bivalent cations i.e., $\mathrm{Cd}(\mathrm{II}), \mathrm{Zn}(\mathrm{II}), \mathrm{Cu}(\mathrm{II})$ and $\mathrm{Pb}(\mathrm{II})$ from aqueous solutions in the presence of $0.01 \mathrm{M} \mathrm{NaNO}$ (Vaclavikova et al., 2005). The red mud showed relatively high uptake of cadmium and zinc from near-neutral aqueous solutions (maximum uptake capacity for cadmium: $68 \mathrm{mg} / \mathrm{g}$ at $\mathrm{pH} 6$ and $133 \mathrm{mg} / \mathrm{g}$ for zinc at $\mathrm{pH}$ 7).

Papandreou et al. (2007) used fly ash to prepare pellets of diameter in-between 3-8 $\mathrm{mm}$ with good mechanical strength and high relative porosity. The pellets were used in adsorption experiments for the removal of copper and cadmium ions from aqueous solutions. The experimental parameters chosen were: agitation rate, equilibration time, $\mathrm{pH}$ of solution and initial metal concentration. The adsorption of both cations followed pseudo-second order kinetics reaching equilibrium after an equilibration time of $72 \mathrm{~h}$. The experimental results for copper and cadmium adsorption fitted well to a Langmuir type isotherm. The calculated adsorption capacities of pellets for copper and cadmium were reported as 20.92 and $18.98 \mathrm{mg} / \mathrm{g}$, respectively. 
The possibility of the utilization of coal fly ash as a low cost adsorbent material for the adsorption of heavy metal ions ( $\mathrm{Zn}$ (II), $\mathrm{Pb}(\mathrm{II}), \mathrm{Cd}(\mathrm{II}), \mathrm{Mn}(\mathrm{II})$ and $\mathrm{Cu}(\mathrm{II})$ ) has been reported (Mohan and Gandhimathi, 2009). Experimental data were evaluated to find out kinetic characteristics of the adsorption process. The isothermal data could be well described by the Freundlich adsorption model. The fly ash concentration required to achieve maximum heavy metal removal was found to be $2 \mathrm{~g} / \mathrm{L}$ with the removal efficiencies of $39 \%, 28 \%, 74 \%, 42 \%$ and $71 \%$ for $\mathrm{Cu}(\mathrm{II}), \mathrm{Mn}(\mathrm{II}), \mathrm{Pb}(\mathrm{II}), \mathrm{Zn}(\mathrm{II})$ and $\mathrm{Cd}(\mathrm{II})$ respectively. The results of the study demonstrated that the fly ash could be used as an effective adsorbent with low cost for the removal of heavy metal ions. $\mathrm{Pb}(\mathrm{II})$, $\mathrm{Ni}(\mathrm{II}), \mathrm{Cu}(\mathrm{II}), \mathrm{Cd}(\mathrm{II})$ and $\mathrm{Zn}$ (II) removal from contaminated liquids has been studied on different types of fly ashes (Chaiyasith et al., 2006; Koukouzas et al., 2010). The results of various studies suggest that fly ash may be a promising adsorbent provided for environmental technologies in the future.

\subsubsection{Biosorbents}

2.5.3.1 Micro-organism based biosorbents: Since 1990's the biosorption of heavy metal ions by low cost renewable organic materials has gained momentum. The uptake of both metal and non-metal species by biomass, whether living or denatured, is commonly termed as biosorption. The major advantages of bio-biosorption over other conventional treatment methods are: (i) low cost, (ii) high efficiency of metal removal from dilute solution, (iii) no additional nutrient requirements, (iv) regeneration and recycling of the bio-sorbent and (v) possibility of metal recovery.

An increased amount of attention is being focused (Volesky, 1990; Matheickal et al., 1991; Fourest and Roux, 1992; Williams et al., 1998) on biosorption as it utilizes the ability of biological materials to accumulate heavy metals from waste streams by either metabolically mediated, or purely physico-chemical pathways of uptake. The biological materials that have been investigated for cadmium uptake include fungi (Matheickal et al., 1991; Fourest et al., 1994), bacteria (Scott and Palmer, 1990; Chang et al., 1997), yeast (Volesky et al., 1993), micro-algae (Harris and Ramelow, 1990; Fehrmann and Pohl, 1993), and others (Azab and Peterson, 1989; Delgado et al., 1993). The maximum cadmium biosorption by these materials ranges from $30.35 \mathrm{mg}$ per $\mathrm{g}$ for fungus to $100 \mathrm{mg}$ per g for micro-algae. Waste biomass Sargassum sp. (Esteves et al., 2000) was reported to remove 100\% of cadmium from $98 \mathrm{mg} / \mathrm{L}$ solution at $\mathrm{pH}$ 4.5. Desorption studies were also reported using $\mathrm{CaCl}_{2}$ solution. Hsu and Chiang (1991) reported that Acinetobacter calca var. antratus biomass can effectively remove cadmium ions from waste waters. Naturally available inexpensive materials, e.g. fungal biomass, and agricultural and animal waste, were used as biosorbents by Azab and Peterson (1989). They found that ten of the tested materials showed a higher adsorption capacity than that of activated charcoal and ion-exchange resin. Due to high affinity of the adsorbent for the metal ion species, the latter is attracted and bound by rather complex process affected by several mechanisms involving chemisorption, complexation, adsorption on surface and pores, ion exchange, chelation, adsorption by physical forces, entrapment in inter and intrafibrillar capillaries and spaces of the structural polysaccharides network as a result of the concentration gradient and diffusion through cell wall and membrane (Sarkanen and Ludwig, 1971; Basso et al., 2002). Different microorganism-derived materials have also been used as biosorbents (Holan et al., 1993; Volesky and Holan, 1995; Hamdy, 2000; Vieira and Volesky, 2000; Barros et al., 2003; Arkipo et al., 2004; Lodeiro et al., 2004; Mata et al., 2008; Sar1 and Tuzen, 2008). The nature and type of biosorbent can affect the amount of metal uptake. Out of different algae, brown algae Fucus vesiculosus (Mata et al., 2008) has greater uptakes than green or red algae. Some of the algae materials used to remove cadmium from waste waters are green algae Chlorella emersonii (Arkipo et al., 2004), Sargassum muticum (Loderro et al., 2004 , Ascophyllum sargassum, (Volesky and Holan, 1995) red algae Ceramium virgatum (Hamdy, 2000). It is reported that Aspergillus niger (fungus) (Barros et al., 2003) is effective in removing cadmium. Yeast species (Bashar et al.,2003) (Saccharomy cescerevisiae, Kluyveromyces fragilis) were also tried to remove cadmium from industrial effluents. Biosorption by algae has been mainly attributed to the cell wall structure containing functional groups such as amino, hydroxyl, carboxyl and sulphate, which can act as binding sites for metals via both electrostatic attraction and complexation (Beveridge and Murray, 1980).

\subsubsection{Agricultural based biosorbents (stems, peels, husks, shells, leaves etc.)}

Agricultural waste materials are usually composed of lignin and cellulose as the main constituents. Other components are hemicellulose, extractives, lipids, proteins, simple sugars, starches, water, hydrocarbons, ash and many more compounds that contain a variety of functional groups present in the binding process. The functional groups present in biomass molecules are: acetamido groups, carbonyl, phenolic, structural polysaccharides, amido, amino, sulphydryl carboxyl groups, alcohols and esters (Beveridge and Murray, 1980; Gupta and Ali, 2000). These groups have the ability to bind heavy metal by replacement of hydrogen ions for metal ions in solution or by donation of an electron pair from these groups to form complexes with the metal ions in solution. Some biosorbents are non-selective and bind to a wide range of heavy metals with no specific priority, whereas others are specific for certain types of metals depending upon their chemical composition. The presence of various functional groups and their complexation with heavy metals during biosorption process has been reported by different research workers using spectroscopic techniques (Tarley and Arruda 2004). A number of reviews have appeared highlighting the potential of low-cost adsorbents prepared from agricultural waste materials (Bailey et al., 1999; Babel and Kurniawan 2003 Kurniawan et al., 2006; Sud et al., 2008; Reddy et al., 2009). Heavy metal removal by agro based waste material was reported by Qaiser et al. (2007). Bennaissa (2006) compared the abilities of four low-cost materials: peels of peas, broad bean, medlar and fig leaves, to remove 
cadmium from aqueous solutions. A high cadmium adsorption was observed by these materials. The broad bean peel was the most effective to remove cadmium ions with a maximum adsorption capacity of $147.7 \mathrm{mg} / \mathrm{g}$ followed by peas peel $(118.9 \mathrm{mg} / \mathrm{g})$, fig leaves $(103.1 \mathrm{mg} / \mathrm{g})$, and medlar peel $(98.1 \mathrm{mg} / \mathrm{g})$.

Saw dust as the biosorbent: Saw dust, being cheap and easily available, has been widely studied to remove metal ions from waste water either as such or in the treated form. Memon et al. (2007) carried out a detailed study on treated and untreated saw dust. The initial adsorption kinetics was observed to be very fast with $97 \%$ of $\mathrm{Cd}(\mathrm{II})$ getting removed within eight minutes. The isothermic data was treated for fitting using D-R and Langmuir models. The desorption studies using dilute $\mathrm{HCl}$ were also carried out to regenerate the biosorbent. Fixation of heavy metal ions $\mathrm{Cd}(\mathrm{II})$ and $\mathrm{Pb}(\mathrm{II})$ ) onto sawdust of Pinus sylvestris has been discussed by Costodes et al. (2003). The ability of saw dust and neem bark as low-cost natural adsorbents were investigated for adsorptive removal of $\mathrm{Zn}(\mathrm{II})$ and $\mathrm{Cd}(\mathrm{II})$ ions from aqueous solutions (Naiya et al., 2009). The adsorption energy calculated by using Dubinin-Radushkevich isotherm for different systems indicated that the adsorption process is physical in nature. Poplar wood sawdust was examined for adsorption of copper, zinc and cadmium from electroplating wastewater (Sciban et al., 2007), modified hardwood saw dust (Sciban et al., 2006) as well as papaya wood (Saeed et al., 2005) were also examined.

Barks as biosobents: Equilibrium and kinetics studies were carried out with pine bark (Al-Asheh and Duvnjak, 1997; Al-Asheh and Duvnjak, 1998).The efficiency of eucalyptus bark as a low cost adsorbent for removing cadmium ions from aqueous solution has been investigated in batch mode (Ghodbane et al., 2007). The five linearized forms of the Langmuir equation as well as the non-linear curve fitting analysis method were discussed. Results showed that the non-linear method may be a better way to obtain the Langmuir parameters. The kinetics of cadmium adsorption on to tree fern has been investigated (Ho and Wang 2004). The experimental results were analyzed by pseudo-Langmuir, pseudo-Freundlich and pseudo-Redlich-Peterson isotherms based on pseudo-second order kinetic expression constant. Both pseudo-Langmuir and pseudo-Redlich-Peterson isotherms were found to well represent the measured adsorption data. The ambient temperature adsorption of the metal cations $\mathrm{Zn}(\mathrm{II}), \mathrm{Cu}(\mathrm{II})$ and $\mathrm{Pb}(\mathrm{II})$ on Pinus pinaster bark pretreated with acidified formaldehyde solution has also been reported (Vázquez et al., 1994). The bark was found to be an excellent adsorbent, suitable for removal of toxic ions from wastewater with efficiency comparable to commercially available adsorbents, but at a much reduced cost. The abilities of 15 coniferous barks for removing toxic heavy metal ions were investigated (Seki et al., 1997). Of the barks tested, high adsorption ability for heavy metal ions was found in Picea abies (Norway Spruce). The continuous column experiments using $P$. jezoensis bark for $\mathrm{Cd}(\mathrm{II})$ adsorption indicated that packing had retained $10.1-14.2 \mathrm{mg} / \mathrm{g}$ adsorbent until the column broke through.

Stems as biosorbents: Tan and Xiao (2009) examined the utility of ground wheat stems to remove cadmium. They observed that blocking of the functional groups decreased the binding capacity of cadmium whereas increasing functional groups enhanced the binding capacity. FTIR spectrum confirmed that $\mathrm{COO}^{-}$is the main active group present in the adsorbent and XPS data indicated that cadmium was adsorbed as $\mathrm{Cd}$ (II) and attached to $\mathrm{O}^{-}$. Kinetic and equilibrium studies were carried out with wheat straws (Dang et al., 2009). Efforts were made to utilize sunflower stalks (Sun and Shi,1998) to remove cadmium. Experiments using grapes stalks (Martínez et al., 2006) revealed that the presence of $\mathrm{NaCl}_{\text {and }} \mathrm{NaClO}_{4}$ in the solution caused a reduction in $\mathrm{Pb}$ (II) and $\mathrm{Cd}(\mathrm{II})$ adsorption. $\mathrm{HCl}$ or EDTA solutions were able to desorb lead from the grape stalks completely, while an approximately $65 \%$ desorption yield was obtained for cadmium. From the results obtained it seems that other mechanisms, such as surface complexation and electrostatic interactions must be involved in the metal adsorption in addition to ion exchange.

Shells as biosorbents: Hazelnut shell, an agricultural waste, is abundantly available in Sisily which is usually used as solid fuel. Cimino et al. (2000) found conditions for utilization of hazel nut shell to remove cadmium, zinc, chromium(III) and (V) from wastewaters. Cadmium adsorption studies were also carried out on pellets of peanut hulls by Brown et al. (2000). The use of the coconut shell as a biosorbent material presents strong potential due to its high content of lignin $(\sim 35-45 \%)$, and cellulose $(\sim 23-$ $43 \%$ ). Powder of coconut shell Cocos nucifera (Pino et al., 2006) is an attractive and inexpensive option for the biosorption removal of dissolved metals. Various metal-binding mechanisms are thought to be involved in the biosorption process including ion exchange, surface adsorption, chemisorption, complexation, and adsorption-complexation.

Peels as biosorbents: Orange peel (Li et al., 2007) modified with $0.6 \mathrm{~mol} / \mathrm{L}$ citric acid under $80^{\circ} \mathrm{C}$ after alkali saponification was found to be effective in removing cadmium from waste waters. Desorption was done with $0.15 \mathrm{~mol} / \mathrm{L} \mathrm{HCl}$. Treatment of jackfruit peel (Inbaraj and Sulochana, 2004) with sulphuric acid produced a carbonaceous product which was used to study its efficiency as an adsorbent for the removal of $\mathrm{Cd}(\mathrm{II})$ from aqueous solution. Reports are also available for the use of banana and orange peels (Annadurai et al., 2002) to remove cadmium. Iqbal et al. (2009) studied cadmium and lead adsorption with mango peels waste. Their FTIR analysis revealed that carboxyl and hydroxyl functional groups were mainly responsible for the adsorption of $\mathrm{Cd}^{2+}$ and $\mathrm{Pb}(\mathrm{II})$. Chemical modification of MPW for blocking of carboxyl and hydroxyl groups showed that $72.46 \%$ and $76.26 \%$ removal of $\mathrm{Cd}(\mathrm{II})$ and $\mathrm{Pb}$ (II), respectively, was due to the involvement of carboxylic group, whereas $26.64 \%$ and $23.74 \%$ was due to the hydroxyl group. EDX analysis of MPW before and after metal adsorption and release of cations $\left(\mathrm{Ca}^{2+}, \mathrm{Mg}^{2+}, \mathrm{Na}^{+}, \mathrm{K}^{+}\right)$and proton $\mathrm{H}^{+}$from MPW with the corresponding uptake of $\mathrm{Cd}(\mathrm{II})$ and $\mathrm{Pb}(\mathrm{II})$ revealed that the main mechanism of adsorption was by ion 
exchange. The regeneration experiments showed that the MPW could be reused for five cycles without significant loss in its initial adsorption capacity.

Husks as biosorbents: Husk of lathyrus sativus was used by Panda et al. (2006) They have reported that scanning electron micrographs showed that cadmium to be present as micro precipitate on the surface of the adsorbent. Cadmium replaced calcium of the biomass as revealed from the EDX analysis indicating that the adsorption proceeds through ion exchange mechanism. Cadmium could be desorbed from the loaded biomass by lowering $\mathrm{pH} 1.0$ with mineral acid. Husk of black gram (Cicer arientinum) (Saeed and Iqbal, 2003), a waste of no commercial value, was investigated as a new biosorbent of cadmium from low concentration aqueous solutions. The researchers used both batch and continuous columns for their studies. Biosorption of cadmium was not affected in the presence of other cations. Ajmal et al. (2003) studied the removal and recovery of cadmium from waste waters using rice husk. Sodium carbonate treated rice husk was used in a fixed bed column for the removal of Cd(II) from water environment (Kumar and Bandyopadhyay, 2006a). Kumar and Bandyopadhyay (2006b) used some simple and low-cost chemical modifications to increase the adsorption capacity of raw rice husk (RRH). Epichlorohydrin treated rice husk (ERH) increased the capacity from $8.58 \mathrm{mg} / \mathrm{g}$ to $11.12 \mathrm{mg} / \mathrm{g}, \mathrm{NaOH}$ treated rice husk (NRH) increased to $20.24 \mathrm{mg} / \mathrm{g}$ and sodium bicarbonate treated rice husk (NCRH) increased to $16.18 \mathrm{mg} / \mathrm{g}$ and reducing the equilibrium time from $10 \mathrm{~h}$ of RRH to 2,4 and 1 $\mathrm{h}$ respectively. Krishnani et al. (2008) have reported detailed studies carried out on adsorption of nine heavy metals using rice husk.

Bran/grains as biosorbents: Rice bran was evaluated for its potential use as a biosorbent for $\mathrm{Cd}(\mathrm{II}), \mathrm{Cu}(\mathrm{II}), \mathrm{Pb}(\mathrm{II})$ and $\mathrm{Zn}(\mathrm{II})$ (Montanher et al., 2005) and FTIR, SEM, BET studies were incorporated. A novel biosorbent rice polish has been successfully utilized for the removal of cadmium(II) from wastewater (Singh et al., 2005) - A generalized empirical model was proposed for the kinetics at different initial concentrations. The data were subjected to multiple regression analysis and a model was developed to predict the removal of $\mathrm{Cd}(\mathrm{II})$ from wastewater. Wheat bran and treated wheat bran (Farajzadeh and Monji , 2004; Ozer and Pirincci, 2006; Singh et al., 2006; Nouri et al., 2007) have attracted the attention of many researchers. Low et al. (2000) studied the use of spent grain, a byproduct of brewing industry, as adsorbent to remove cadmium and lead from aqueous solutions. A new biosorbent, kraft lignin, for removing toxic metal ions from water/ industrial wastewater has been investigated using by-product lignin from paper production (Mohan et al., 2006). Lignin was extracted from waste black liquor, characterized and utilized for the removal of copper and cadmium from solutions in single, binary and multi-component systems. The adsorption capacity of black liquor lignin was found to be higher than many other adsorbents/ carbons/ biosorbents utilized for the removal of $\mathrm{Cu}(\mathrm{II}) \mathrm{and} \mathrm{Cd}(\mathrm{II})$ from water/wastewater in single and multi-component systems. Adsorption isotherms were determined experimentally for Cd(II) adsorption from solution onto natural and oxidized corncob in a batch adsorber (Ramos et al., 2005; Shen and Duvnjak, 2005). The adsorption capacity of corncob was increased 10.8 and 3.8 times when the corncob was oxidized with citric acid (CA) and nitric acid (NA), respectively. The Cd(II) ions were adsorbed mainly on the carboxylic sites.

Leaves as biosorbents: Sharma and Bhattacharya (2005) studied adsorption of cadmium using neem leaf powder. The kinetics of the interactions was tested with pseudo-first-order Lagergren equation, simple second order kinetics, Elovich equation, liquid film diffusion model and intra-particle diffusion mechanism. The leaves of olive tree (Olea europaea) were proposed (Hamdaoui, 2009) as a novel low-cost non-conventional adsorbent for the removal of cadmium from solutions with and without the assistance of ultrasound and by associating simultaneously ultrasonic irradiation and stirring. It was reported that adsorption was significantly increased in the presence of ultra sound. A batch adsorption study of $\mathrm{Cd}(\mathrm{II})$ ions from aqueous solution by Hevea Brasiliensis (HB) leaf powder has also been reported (Hanafiah et al., 2006). The cadmium removing capacity of a biosorbent Calotropis procera (Pandey et al., 2008), a perennial wild plant, was investigated. The FTIR analysis indicated the involvement of hydroxyl $(-\mathrm{OH})$, alkanes $(-\mathrm{CH})$, nitrite $\left(-\mathrm{NO}_{2}\right)$, and carboxyl group $(-\mathrm{COO})$ chelates in metal binding. The complete desorption of the cadmium was achieved by $0.1 \mathrm{M} \mathrm{H}_{2} \mathrm{SO}_{4}$ and $0.1 \mathrm{M} \mathrm{HCl}$. Recently Rao et al. have carried out extensive studies on $\mathrm{Cd}(\mathrm{II})$ adsorption taking powdered leaves of a variety of trees (2010a, 2010b, $2010 \mathrm{c}, 2010 \mathrm{~d}, 2010 \mathrm{e}, 2010 \mathrm{f}$ )

\subsubsection{Biosorption with agro-industrial waste materials}

A number of adsorbents obtained from agro-industrial waste materials were used to remove cadmium from wastewaters. Teaindustry waste (Mahvi et al., 2005; Cay et al., 2004) was used to remove lead, cadmium and nickel. It was found that the order of removal was $\mathrm{Pb}>\mathrm{Ni}>\mathrm{Cd}$. A number of other researchers (Tee and Khan, 1988; Ahluwalia and Goyal, 2005) have also evaluated the potential of waste tea leaves to remove cadmium from waste waters. Areca-food waste (Zheng et al., 2008) was used to separate cadmium and copper from wastewaters. This material has potential metal binding active sites due to rich cellulosic content. The mechanism involved may be ion-exchange and surface adsorption. Desorption of metal ions was possible by just controlling $\mathrm{pH}$. Many researchers studied removal of cadmium from waste waters using sugarcane bagasse (Ibrahim et al., 2006), chemically modified sugarcane bagasse (Karnitz Jr. et al., 2007), and sugar industry waste (bagasse fly ash). Pehlivan et al's (2008) results with sugar beet pulp indicated that the metal ions were removed exclusively by ion exchange, physical adsorption and chelation. Addition of $0.1 \mathrm{M} \mathrm{NaNO}_{3}$ improved the metal ion uptake. Degreased coffee beans (Kaikake et al., 2007) found a 
place in removing cadmium. The authors characterized the adsorbent by FTIR, XRF and SEM. They have reported that it contained sulphur and calcium and had porous structure. Apple residue (Lee et al., 1998) was used to remove cadmium, copper and lead. The results indicated that apple residues modified with phosphorous(V) oxychloride improved their physico-chemical properties and exhibited greatly enhanced capacity for metal removal. Cassava waste (Abia et al., 2003) is another industrial waste which has been tried for removal of cadmium from solutions. The waste was treated with thioglycollic acid to modify the cassava waste which resulted in enhancement of metal ion removal capacity. Adsorption studies carried out for cation removal on agricultural waste, (Orhan and Bujukgungor, 1993) agro based waste (Qaiser et al. 2007), solid residue of olive mill products (Gharaibeh et al., 1998) have also been reported.

The cadmium uptake capacities of some of the adsorbents are given in Tables 2a to 2d. It is observed from the Tables 2a to $2 \mathrm{~d}$ that there are a number of adsorbents in different categories exhibiting high uptake capacities. Some of the adsorbents such as mesoporous silica, mesoporous silicate MCM-41, Haldmand Ah soil, Halimond Ap soil, broad been peel, fig leaves, Kraft lignin, Platanus Orientalis, Medlar peel, peas peel, rice husk, modified sugarcane bagasse, modified wheat bran, aliginate carriers, alcaligenes eutrophus, baker's yeast etc., have Cd(II) uptake capacities $\geq 90 \mathrm{mg} / \mathrm{g}$. A number of oxide materials have also shown high loading capacities.

Table2a Naturally occurring and waste materials as adsorbents for removal of cadmium from aqueous solutions

\begin{tabular}{lcl}
\hline Adsorbent & $\mathrm{q}_{\max }(\mathrm{mg} / \mathrm{g})$ & Reference \\
\hline Aluminosilicates & $42.7-57.9$ & (Rangel et al., 2006) \\
Calcite & 18.52 & (Yavuz et al., 2007) \\
Chemically treated clay & 12.6 & (Samir, 2008) \\
Chromite mine overburden & 22.47 & (Mohapatra et al., 2007; 2009c) \\
Fly ash, treated & 14.33 & (Chaiyasith et al., 2006) \\
Iron ore slime & 34.75 & (Mohapatra et al., 2009b) \\
Low grade manganese ore & 59.17 & (Mohapatra et al., 2008) \\
Manganese nodule residue & 47.60 & (Agarwal and Sahu, 2006) \\
Manganese nodule residue & 21.2 & (Rout et al., 2009) \\
Nalco Plant Sand & 58.13 & (Mohapatra et al., 2009a) \\
Nickel laterite (high iron) & 13.2 & (Mohapatra et al., 2007) \\
Nickel laterite (low iron) & 11.0 & (Mohapatra et al., 2007) \\
Nickel, leaching residue & 25 & (Vaclavikova et al., 2006) \\
Palygorskite & 4.54 & (Ayuso and Sanchez, 2007) \\
Perlite & 0.64 & (Mathialagan and Viraraghavan, 2002) \\
Pumice sand columns & 20 & (Pang et al., 2004) \\
Red bauxite & 38.77 & (Rout et al., 2009) \\
Red mud & 13.03 & (Gupta and Sharma, 2002) \\
Silica, mesoporous & $111.3 \pm 3.3$ & (Ilhan et al., 2004) \\
Silicate MCM-41,mesoporous & 100 & (Oshima et al., 2006) \\
Soil, Cane & 59.5 & (Bolton and Evans, 1996) \\
Soil, Fox & 17.0 & \\
Soil, Guelph & 46.7 & \\
Soil, Haldimand Ah & 99.9 & \\
Soil, Haldimand Ap & 98.0 & \\
Soil, Hanbury & 84.3 & \\
Soil, Welland & 49.9 & \\
Washed and treated clay & 24.45 & \\
Water washed clay & 11.68 & \\
& & \\
(Samir, 2008)
\end{tabular}


Table 2b. Plant wastes as adsorbents for the removal of cadmium ions from aqueous solution

\begin{tabular}{|c|c|c|}
\hline Adsorbent & $\mathrm{q}_{\max }(\mathrm{mg} / \mathrm{g})$ & Reference \\
\hline Broad bean peel & 147.71 & (Benaissa, 2006) \\
\hline Coconut copra meal & 4.92 & (Ho and Ofomaja, 2006) \\
\hline Corncob & 6.43 & (Shen and Duvnjak, 2005) \\
\hline Corncob & 5.09 & (Ramos et al, 2005) \\
\hline Exhausted coffee & 1.48 & (Orhan and Buyukgungor, 1993) \\
\hline Ficus religiosa leaf powder & 27.14 & (Rao et al., 2010d) \\
\hline Fig leaves & 103.09 & (Benaissa, 2006) \\
\hline Grape stalk & 27.88 & (Martinez et al., 2006) \\
\hline Hazelnut shell & 5.42 & (Cimino et al., 2000) \\
\hline Juniper fiber & 29.50 & (Min et al., 2004) \\
\hline Kraft lignin & 137.14 & (Mohan et al., 2006) \\
\hline Lathyrus sativus husk & 35.00 & (Panda et al., 2006) \\
\hline Leaves, Platanus orientalis & 110.00 & (Mahvi et al., 2007) \\
\hline Medlar peel & 98.14 & (Benaissa, 2006) \\
\hline Modified lignin & $6.7-7.50$ & (Demirbbas, 2004) \\
\hline Nanotubes & 11.00 & (Li et al., 2003) \\
\hline Peanut hulls & 5.96 & (Brown et al., 2000) \\
\hline Peas peel & 118.91 & (Benaissa, 2006) \\
\hline Petiolar felt-sheath of palm & 10.80 & (Iqbal et al., 2002) \\
\hline Pine bark & 7.50 & (Asheh and Duvnjak, 1997) \\
\hline Pine cone, ground & 13.56 & (Izanlo et al., 2005) \\
\hline Pinus pinaster bark & 8.00 & (Bailey et al., 1999) \\
\hline Psidium guvajava l leaf powder & 31.15 & (Rao et al., 2010b) \\
\hline Rice husk & 103.09 & (Ajmal et al., 2003) \\
\hline Rice husk & 8.58 & (Kumar and Bandyopadhyay, 2006) \\
\hline Rice polish & 9.72 & (Singh et al., 2005) \\
\hline Sawdust of Pinus sylvestris & 19.09 & (Costodes et al., 2003) \\
\hline Sugar beet pulp & 17.20 & (Zacaria et al., 2002) \\
\hline Syzygium cumini leaf powder & 34.54 & (Rao et al., 2010e) \\
\hline Tea-industry waste & 11.29 & (Cay et al., 2004) \\
\hline Techtona grandis L.f & 23.20 & (Rao et al., 2010a) \\
\hline Terminalia catappa Linn leaf & 35.83 & (Rao et al., 2010c) \\
\hline Tree fern & 16.30 & (Ho and Wang, 2004) \\
\hline Wheat bran & 15.71 & (Nouri et al., 2007) \\
\hline Wheat bran & 0.70 & (Singh et al., 2006) \\
\hline
\end{tabular}

Table2c Modified plant wastes as adsorbents for the removal of cadmium ions from aqueous solution

\begin{tabular}{llcl}
\hline Adsorbent & Modifying agent(s) & $\mathrm{q}_{\max }(\mathrm{mg} / \mathrm{g})$ & Reference \\
\hline Azolla filiculoides(aquatic fern) & Magnesium chloride & 86 & (Ganji et al., 2005) \\
Cassava tuber bark waste & Thioglycollic acid & 26.3 & (Horsfall Jr. et al., 2006) \\
Corncorb & Nitric acid & 19.3 & (Ramos et al., 2005) \\
& Citric acid & 55.2 & \\
Juniper fibre & Sodium hydroxide & 29.54 & (Min et al., 2004) \\
Rice husk & Sodium hydroxide & 20.24 & (Kumar and Bandyopadhyay, 2006) \\
& Sodium bicarbonate & 16.18 & \\
Sawdust(Cedrus deodar wood) & Epichlorohydrin & 11.12 & \\
Saw dust of Pinus sylvestris & Sodium hydroxide & 73.62 & (Memon et al., 2007) \\
& Formaldehyde in & 9.29 & (Costodes et al, 2003) \\
Spent grain & Sulphuric acid & & \\
Sugarcane bagasse & Sodium hydroxide & 17.3 & (Low et al, 2000) \\
& Sodium bicarbonate & 189 & (Junior et al., 2006) \\
& Ethylenediamine & 189 & \\
Wheat bran & Triethylenetetramine & 313 & \\
\hline
\end{tabular}


Table2d Microorganisms as adsorbents for the removal of cadmium from aqueous solutions

\begin{tabular}{lcl}
\hline Adsorbent & $\mathrm{q}_{\max }(\mathrm{mg} / \mathrm{g})$ & Reference \\
\hline Alcaligenes eutrophus & 122 & (Mahvi and Diel, 2004) \\
Algae, marine, dead Biomass & 80 & (Herrero et al., 2006) \\
Algae, Nile water & 37.43 & (Sherif et al., 2008) \\
Alginate Carriers & 220 & (Zadrozna et al., 2004) \\
Ascophyllum nodosum & 38 & (Lodeiro et al., 2005) \\
Aspergillus niger, living & 15.50 & (Liu et al., 2006) \\
Fucus spiralis & $64 \pm 2$ & (Cordero et al., 2004) \\
Saccorhiza polyschides & 95 & (Lodeiro et al., 2005) \\
Water hyacinth & 2.44 & (Lu et al., 2004) \\
Yeast, baker's & 91.74 & (Vasudevan et al., 2003) \\
\hline
\end{tabular}

The literature survey has shown that in most of the cases, adsorption studies were carried out either in stirred tank or upflow reactors. Generally the various adsorption parameters studied to evaluate their effects on $\mathrm{Cd}(\mathrm{II})$ removal efficiency are: contact time, $\mathrm{pH}$, temperature, adsorbate and adsorbent concentrations. Some studies were also carried out for understanding the effect of competing anions and cations. Adsorption kinetics was observed to be reasonably fast and allowed dual rate, i.e. initial faster rate followed by slower one. The initial faster and later slower rates might be due to surface and intra particle diffusion processes respectively. Evaluation of isothermic and thermodynamic parameters has also been outlined as important ones for scale up and reactor design. In addition to process development in small scale, adsorption studies were also carried out in different reactors, which helped in scaling up of the laboratory/bench scale data to pilot or industrial scale. A number of low-cost adsorbents have been projected as potential candidates for removal of cadmium from aqueous solution. There is lack of data on regeneration/reuse and safe disposal of loaded adsorbent. More attention needs to be paid to evaluation of their commercial utilization.

\section{Conclusions}

1. Cadmium(II) is amongst the most toxic ions hazardous to living organism and its permissible limit in drinking water is $0.005 \mathrm{mg} / \mathrm{L}$.

2. Removal of cadmium from aqueous solutions can be accomplished by several techniques which include cementation, chemical precipitation, ion exchange, solvent extraction, membrane separation and adsorption. Adsorption is one of the most studied technique.

3. The main categories of adsorbents are carbon, agricultural wastes, industrial wastes, low grade ores, clays and low cost synthetic oxides/hydroxides such as iron/manganese/ aluminum.

4. Some of the adsorbents with high loading capacities ( $\geq 90 \mathrm{mg} / \mathrm{g})$ are: mesoporous silica, mesoporous silicate MCM-41, Haldmand Ah soil, Halimond Ap soil, broad been peel, fig leaves, Kraft lignin, Platanus Orientalis, Medlar peel, peas peel, rice husk, modified sugarcane bagasse, modified wheat bran, aliginate carriers, alcaligenes eutrophus and baker's yeast.

5. The main experimental parameters which are studied to evaluate the adsorption behaviour are time, $\mathrm{pH}$, temperature, concentration of adsorbate and adsorbent, competing ions etc. The time data is generally fitted to pseudo-first order and pseudo-second order kinetics. The thermodynamic parameters have been evaluated from the temperature data. The isothermic data is fitted to various models such as Langmuir, Freundlich, Temkin etc.

6. Generally the studies are carried out in batch mode though a number of studies are reported for column adsorption also.

7. There is lack of information in literature for regeneration/reuse/safe disposal of loaded adsorbents.

8. The engineering aspects for commercial applications of adsorbents have not been sufficiently studied.

\section{Acknowledgements}

The authors are thankful to the Prof. B. K. Mishra, Director, Institute of Minerals \& Materials Technology, for his kind permission to present this paper. They wish to thank to Dr. R. K. Paramguru, Head, Hydro \& Electro Metallurgy Department.

\section{References}

Abia A.A., Horsefall Jr. M., Didi O., 2003. The use of chemically modified and unmodified cassava waste for the removal of Cd,

$\mathrm{Cu}$ and $\mathrm{Zn}$ ions from aqueous solution. Bioresour. Technol., Vol. 90, pp. 345-348. 
Agrawal A., Sahu K.K., 2006. Kinetic and isotherm studies of cadmium adsorption on manganese nodule residue. J. Hazard. Mater., Vol. B137, pp. 915-924.

Ahluwalia S.S., Goyal D., 2005. Removal of heavy metals by waste tea leaves from aqueous solution. Eng. Life Sci., Vol. 5, pp. $158-162$.

Ahmed S., Chughtai S., Keane M.A., 1998. The removal of cadmium and lead from aqueous solution by ion exchange with Na-Y zeolites. Sep. Puri. Technol., Vol. 13, No.10, pp. 57-64.

Ajmal M., Rao R.A.K., Anwar S., Ahmad J., Ahmad R., 2003. Adsorption studies on rice husk: removal and recovery of Cd(II) from wastewater. Bioresour. Technol., Vol. 86, pp. 147-149.

Al-Asheh S., Duvnjak Z., 1997. Adsorption of cadmium and other metals by pine bark. J. Hazard. Mater., Vol.56, pp. 35-51.

Al-Asheh S., Duvnjak Z., 1998. Binary metal sorption by pine bark: study of equilibria and mechanisms. Sep. Sci. Technol., Vol. 33, pp. 1303-1329.

Alguacil F.J., 2003. A kinetic study of cadmium(II) adsorption on Lewatit TP260 resin. J. Chem. Res., Vol. 3, pp. 144-146.

Alguacil F.J., P. Navarro P., 2001. Permeation of cadmium through a supported liquid membrane impregnated with CYANEX 923, Hydrometallurgy, Vol.61, pp.137-142.

Angove M.J., Johnson B.B., Wells J.D., 1997. Adsorption of cadmium(II) on kaolinite. Colloids Surf. A: Physicochem. Eng. Aspects, Vol. 126, pp. 137- 147.

Annadurai G., Juang R.S., Lee D.L., 2002. Adsorption of heavy metals from water using banana and orange peels. Water Sci. Technol., Vol.47, pp.185-190.

Apak R., Tütem Esma, Hügül Mehmet, Hizal Jülide, 1998. Heavy metal cation retention by unconventional sorbents (red muds and fly ashes). Water Res., Vol.32, No. 2, pp. 430-440.

Arkipo G.E., Kja M.E., Ogbonnaya L.O., 2004. Cd uptake by the green alga Chlorella emersonii. Global J. Pure Appl. Sci., Vol.10, pp. 257-262.

Ayuso E.A., Sanchez A.G., 2007. Removal of cadmium from aqueous solutions by Palygorskite. J. Hazard. Mater., Vol.147, pp. 594-600.

Azab M.S., Peterson P.J., 1989. The removal of cadmium from water by the use of biological sorbents. Water Sci. Technol., Vol. 21, pp.1705-1706.

Babel S., Kurniawan T.A., 2003. Low-cost adsorbents for heavy metals uptake from contaminated water: a review. J. Hazard. Mater., Vol. 97, pp. 219-243.

Bailey S.E., Olin T.J., Bricka R.M., Adrian D.D., 1999. A review of potentially low-cost sorbents for heavy metals. Water Res., Vol.33, pp. 2469-2479.

Barros L.M., Macedo G.R., Duarte M.L., Silva E.P., Lobato A.K.C.L., 2003. Biosorption of Cd using the fungus A. niger. Braz J. Chem. Eng., Vol. 20, pp. 229-239.

Barton S.S., Evans M.J.B., Halliop E., MacDonald J.A.F., 1997. Acidic and basic sites on the surface of the porus carbon. Carbon, Vol. 35, pp. 1361-1366.

Bashar H., Margaritis A., Berutti F., Maurice B., 2003. Kinetics and equilibrium of cadmium biosorption by yeast cells S. cerevisiae and K. fragilis. Int. J. Chem. Reactor. Eng., Vol. 1, pp. 1-16.

Basso M.C., Cerrella E.G., Cukierman A.L., 2002. Lignocellulosic materials as potential biosorbents of trace toxic metals from wastewater. Chem. Res., Vol. 41, pp. 3580-3585.

Bazrafshan E., Mostafapoor F.K., Zazouli M.A., Eskandari Z., Jahed Gh.R., 2006. Study on the removal of cadmium from plating baths wastewater by electrochemical precipitation method, Pakistan J of Biological Sci., Vol.9(11), pp. 2107-2111.

Bell R.R., Saunders G.C., 2005. Cadmium adsorption on hydrous aluminium (III) oxide: effect of adsorbed polyelectrolyte. Applied Geochemistry, Vol. 20, No. 3, pp. 529-536.

Benaissa H., 2006. Screening of new sorbent materials for cadmium removal from aqueous solutions. J. Hazard. Mater., Vol.132, pp.189-195.

Benjamin M.M., Leckie J.O., 1981. Multiple-site sorption of $\mathrm{Cd}, \mathrm{Cu}, \mathrm{Zn}$ and $\mathrm{Pb}$ on amorphous iron oxide, J. Colloid Interface Sci., Vol. 79, pp. 209-221.

Beveridge T.J., Murray R.G.E., 1980. Sites of metal deposition in the cell wall of Bacillus subtilis. J. Biotechnol., Vol. 141, pp. $876-887$.

Bhatnagar A., Minocha A.K., 2009. Utilization of industrial waste for cadmium removal from water and immobilization in cement. Chem. Eng. J., Vol.150, pp. 145-151.

Blokhin A.A., Taushkanov V.P., 1994. Ion-exchange separation of calcium from zinc, cadmium and cobalt salt solutions, $Z h$. Prikl. Khim., Vol. 67, No.7, pp. 1212-1214.

Bolton, K. A., Evans, L. J. 1996.Cadmium adsorption capacity of selected Ontario soils. Can. J. Soil Sci. Vol.5, pp. 183-189.

Breembroek G.R.M., van Straalen A., Witkamp G.J., van Rosmalen G.M., 1998. Extraction of cadmium and copper using hollow fiber supported liquid membranes. J. Membrane Sci., Vol. 146, No. 2, pp. 185-195.

Brown P., Jefcoat I. A., Parrish D., Gill S., Graham E., 2000. Evaluation of the adsorptive capacity of peanut hull pellets for heavy metals in solution. Adv. Environ. Res., Vol. 4, No. 1, pp. 19-29. 
Cay S., Uyanık A., Ozasık A., 2004. Single and binary component adsorption of copper(II) and cadmium(II) from aqueous solutions using tea-industry waste. Sep. Purif. Technol., Vol. 38, pp. 273-280.

Chaiyasith, S., Chaiyasith, P., Septhum, C., 2006. Removal of cadmium and nickel from aqueous solution by adsorption onto treated fly ash from Thailand, Int. J. Sci. Technol., Vol.11, No.2, pp.13-20.

Chang J.S., Law R., Chang C.C., 1997. Biosorption of lead, copper and cadmium by biomass of Pseudomona aeruginosa PU21, Water Res., Vol. 31, pp. 1651-1658.

Chen J., Lin J., Wu X., Yuan X., Zhou J., 1998. Study on adsorption of cadmium with N503 levextrel resin. Chinese J. Nonferrous Metals (China), Vol. 8, No. 3, pp. 507-510.

Cheung C.W., Porter J.F., McKay G., 2000. Elovich equation and modified second- order equation for adsorption of cadmium ions onto bone char. J. Chem. Technol. Biotechnol., Vol. 75, pp. 963-970.

Cheung C.W., Porter J.F., Mckay G., 2001. Adsorption kinetic analysis for the removal of cadmium ions from effluents using bone char. Water Res., Vol. 35, No. 3, pp. 605-612.

Christophi C.A., Axe L., 1999. Competition of Cd, Cu, and Pb adsorption on goethite. J. Environ. Engg., Vol. 126, No.1, pp. 6674.

Cimino G., Passerini A.,Toscano G., 2000. Removal of toxic cations and $\mathrm{Cr}(\mathrm{VI})$ from aqueous solution by hazelnut shell. Water Res., Vol. 34, pp. 2955-2962.

Clifford D., Subramonian S., Sorg T.J., 1986. Water treatment processes. III. Removing dissolved inorganic contaminants from water. Environ. Sci. Technol., Vol. 20, pp. 1072-1080.

Collins C.R., Ragnarsdottir K.V., Sherman D.M., 1999. Effect of inorganic and organic ligands on the mechanism of cadmium sorption to goethite. Geochimica et Cosmochimica Acta, Vol. 63, pp. 2989-3002.

Cordero B., Lodeiro P., Herrero R., Sastre de Vicente M. E., 2004. Biosorption of cadmium by Fucus spiralis, Environ. Chem., Vol.1, pp. 180-187.

Cornelis H., Weijden van der, 1976. Experiments on the uptake of zinc and cadmium by manganese oxides. Marine Chemistry, Vol.4, No. 4, pp. 377-387.

Cornell R.M., Schwertmann U., 1996. In: The Iron Oxides: Structures, Properties, Reactions, Occurrences and Uses. VCH Weinheim, pp. 395-432.

Costodes T.V.C., Fauduet H., Porte C., Delacroix A., 2003. Removal of $\mathrm{Cd}(\mathrm{II})$ and $\mathrm{Pb}(\mathrm{II})$ ions, from aqueous solutions, by adsorption onto sawdust of Pinus sylvestris. J. Hazard. Mater., Vol. B105, pp. 121-142.

Coughlin B.R., Stone A.T., 1995. Nonreversible adsorption of divalent metal ions ( $\mathrm{Mn}, \mathrm{Co}, \mathrm{Ni}, \mathrm{Cu}$, and $\mathrm{Pb}$ ) onto goethite: Effects of acidification, Fe addition, and picolinic acid addition. Environ. Sci. Technol., Vol,29, pp. 2445-2455.

Dabrowski A., Hubicki Z., Podkoscielny P., Robens E., 2004. Selective removal of the heavy metal ions from waters and industrial wastewaters by ion exchange methods. Chemosphere, Vol. 56, pp. 91-106.

Dang V.B.H., Doan H.D., Dang-Vu T., A. Lohi, 2009. Equilibrium and kinetics of biosorption of cadmium(II) and copper(II) ions by wheat straw. Bioresour. Technol., Vol. 100, No.1, pp. 211-219.

Delgado M., Bigeriego M., Guardiola E., 1993. Uptake of Zn, Cr and Cd by water hyacinths. Water Res., Vol. 27, pp. $269-272$.

Deliyanni E.A, Bakoyannakis D.N., Zouboulis A.I., Matis K.A., 2003. Sorption of As(V) ions by akaganeite-type nanocrystals. Chemosphere, Vol. 50, pp. 155-163.

Deliyanni E.A., Matis K.A.,2005. Sorption of Cd ions onto akagan'eite-type nanocrystals. Sep. Puri. Technol., Vol.45, pp. 96-102.

De-ming D., Xing-min Z., Xiu-yi H., Jing-jing Z., Shi-ming W. U., 2007. Lead and cadmium adsorption onto iron oxides and manganese oxides in the natural surface coatings collected on natural substances in the Songhua River of China, Chemical Research in Chinese Universities, Vol. 23, No. 6, pp. 659-664.

Demirbas, A., 2004. Adsorption of lead and cadmium ions in aqueous solutions onto modified lignin from alkali glycerol delignication, J. Hazard. Mater., Vol.B109, pp. 221-226.

Dubinin M.M., 1975. Adsorption and porosity-WAT, Warsaw.

Dzombak D.A., Morel F.M.M., 1990. Surface complexation modeling. Hydrous ferric oxide. Wiley-Interscience: New York, p. 331.

Esteves A.J.P., Valdman E., Leite S.G.F., 2000. Repeated removal of cadmium and zinc from an industrial effluent by waste biomass Sargassum sp. Biotechnol. Lett., Vol. 22, No.6, pp. 499-502.

Farajzadeh M.A., Monji A.B., 2004. Adsorption characteristics of wheat bran towards heavy metal cations. Sep. Puri. Technol., Vol. 38, pp. 197-207.

Farrah H., Pickering F., 1977. The sorption of lead and cadmium species by clay minerals. Aust. J. Chem., Vol. 30, pp. 1417-22.

Fehrmann C., Pohl P., 1993. Cadmium adsorption by the non-living biomass of micro-algae grown in axenic mass culture. J. Appl. Phycol., Vol.5, pp.555-562.

Fendorf S., Eick M. J., Grossl P., Sparks D.L., 1997. Arsenate and chromate retention mechanism on Goethite : 1 Surface structure. Environ Sci Technol, Vol. 31, pp. 315-320.

Fernandez Y., Maranon E., Castrillon L., I. Vazquez I., 2005. Removal of Cd and Zn from inorganic industrial waste leachate by ion exchange J. Hazard. Mater., Vol. B126, 169-175 
Ferro-García M.A., Rivera-Utrilla J., Rodríguez-Gordillo J., Bautista-Toledo I., 1988. Adsorption of zinc, cadmium, and copper on activated carbons obtained from agricultural by-products. Carbon, Vol. 26, No. 3, pp. 363-373.

Forbes E.A., Posner A.M., Quirk J.P., 1976. The specific sorption of divalent $\mathrm{Cd}, \mathrm{Co}, \mathrm{Cu}, \mathrm{Pb}$, and $\mathrm{Zn}$ on goethite, J. Soil Sci., Vol.27, pp.154-188.

Forstner V., Wittman G.T.W., 1981. Metal pollution in the aquatic environment. Springer-Verlag, Heidelberg,Germany.

Fourest E., Canal C., Roux J.C., 1994. Improvement of heavy metal biosorption by mycelial dead biomasses (Rhizopus arrhizus, Muchor miehei, and Pencillium chry-sogenum): pH control and cationic activation. FEMS Microbiol. Rev., Vol.14, pp. 325-332.

Fourest E., Roux J., 1992. Heavy metal biosorption by fungal mycelial by-products: mechanisms and influence of pH. Applied Micro. Biotech., Vol. 37, pp. 399-403.

Gharaibeh S.H., Abu-El-Sha'r W.Y., Al-Kofahi M.M., 1998. Removal of selected heavy metals from aqueous solutions using processed solid residue of olive mill products. Water Res., Vol.32, No.2, pp. 498-502.

Ghodbane I., Nouri L., Hamdaoui O., Chiha M., 2007. Kinetic and equilibrium study for the adsorption of cadmium(II) ions from aqueous phase by eucalyptus bark. J. Hazard. Mater., Vol.152, pp.148-158.

Gomez-serrano V., Macias-garcia A., Espinosa-mansilla A., Valenzuela-calahorro C., 1998. Adsorption of mercury, cadmium and lead from aqueous solution on heat-treated and sulphurized activated carbon. Water Res., Vol. 32, No.1, pp. 1-4.

Gould J. P., Wiedeman H. F., Khudenko B. M., 1986. Cadmium removal and recovery by magnesium cementation. Report-1986 Proj. USGS-G-1011.

Grayson M., Othumer K., 1978. Encyclopedia of Chemical Technology, 43rd ed., John Wiley \& Sons.

Gupta B., Deep A., Malik P., 2001. Extraction and recovery of cadmium using Cyanex 923. Hydrometallurgy, Vol. 61, pp. 65-71.

Gupta V.K., Ali I., 2000. Utilization of bagasse fly ash (a sugar industry waste) for the removal of copper and zinc from wastewater. Sep. Puri. Technol., Vol.18, pp. 131-140.

Gupta V.K., Sharma S., 2002. Removal of cadmium and zinc from aqueous solutions using red mud. Environ. Sci. Technol., Vol. 36, pp. 3612-3617.

Hamdaoui O., 2009. Removal of cadmium from aqueous medium under ultrasound assistance using olive leaves as adsorbent, Chem. Eng. and Proce: Proc. Intensification., Vol.48, No. 6, pp. 1157-1166.

Hamdy A.A., 2000. Biosorption of heavy metals by marine algae. Curr. Microbiol., Vol. 41, pp. 232-238.

Han S.W., Kim D.K., Hwang I.G., Bae J.H., 2002. Development of pellet-type adsorbents for removal of heavy metal ions from aqueous solutions using red mud. J. Ind. Eng. Chem. Vol.8, pp. 120-125.

Hanafiah M.A.K.M., Shafiei S., Harun M.K., Yahya M.Z.A., 2006. Kinetic and thermodynamic study of $\mathrm{Cd}^{2+}$ adsorption onto rubber tree (hevea brasiliensis) leaf powder. Mater. Sci. Forum, Vol.517, pp. 217-221.

Harris P.O., Ramelow G.J., 1990. Binding of metal ions by particulate biomass derived from Chlorella vul-garis and Scendesmus quadricauda. Environ. Sci.Technol., Vol. 24, pp. 220-228.

He D., Gu, S., Ming Ma M., 2007. Simultaneous removal and recovery of cadmium (II) and CN- from simulated electroplating rinse wastewater by a strip dispersion hybrid liquid membrane (SDHLM) containing double carrier, J. Membrane Sci., Vol. 305, pp. 36-47

Heijman S.G.J., Paassen A.M., Meer W.G., Hopman J.R., 1999. Adsorptive removal of natural organic matter during drinking water treatment. Water Sci. Technol., Vol. 40, pp. 183-190.

Herrero R., Cordero B., Lodeiro P., Rey-Castro, C., Sastre de Vicente, M. E., 2006. Interactions of cadmium(II) and protons with dead biomass of marine algae Fucus sp, Mar. Chem., Vol. 99, No.1-4, pp. 106-116.

Hizal J., Apak R., 2006. Modeling of cadmium(II) adsorption on kaolinite-based clays in the absence and presence of humic acid. App. Clay Sci., Vol.32, No. 3-4, pp. 232-244.

Ho Y.S., Ofomaja A.E., 2006. Biosorption thermodynamics of cadmium on coconut copra meal as biosorbent, Biochem. Eng. J. Vol.30, pp. 117-123.

Ho Y.S., Wang C.C., 2004. Pseudo-isotherms for the adsorption of cadmium ion onto tree fern. Process Biochem., Vol. 39, pp.759-763.

Holan Z.R., Volesky B., Prasetyo I., 1993. Biosorption of cadmium by biomass of marine algae. Biotechnol. Bioeng., Vol.41, pp. 819-825.

Hsu J.P., Chiang T.Y., 1991. Removal of cadmium ions in wastewater through biosorption. World J. Microbio. Biotechnol., Vol.7, No.5, pp.571-572.

Ibrahim S.C., Hanafia M.A.K.M., Yahya M.A.Z., 2006. Removal of cadmium from aqueous solutions by adsorption onto sugarcane bagasse. American-Eurrasian J. Agric.\& Environ., Vol.1, No. 3, pp. 179-184.

Inbaraj B.S., Sulochana N., 2004. Carbonised jackfruit peel as an adsorbent for the removal of Cd(II) from aqueous solution. Bioresour. Technol., Vol. 94, pp. 49-52.

Iqbal, M. Saeed A. and Akhtar, N., 2002. Petiolar felt-sheath of palm - a new biosorbent for the removal of heavy metals from contaminated water, Bioresour. Technol., Vol.81, pp. 151-153.

Iqbal M., Saeed A., Zafar S.I., 2009. FTIR Spectrophotometry, kinetics and adsorption isotherms modeling, ion exchange, and EDX analysis for understanding the mechanism of $\mathrm{Cd}^{2+}$ and $\mathrm{Pb}^{2+}$ removal by mango peel waste. J. Hazard. Mater., Vol.164, pp.161-171. 
Islamoglu S., Yilmaz L., Ozbelge H.O., 2006. Development of a precipitation based separation scheme for selective removal and recovery of heavy metals from cadmium rich electroplating industry effluents. Sep. Sci. Technol. Vol. 41, pp. 3367-3385.

Izanloo H., Nasseri S., 2005. Cadmium removal from aqueous solutions by ground pine cone, Iran. J. Environ. Health Sci. Eng., Vol. 2 (1), pp.33-42.

Jia Q., Zhan C.H., Li D.Q., Niu C.J., 2004. Extraction of zinc(II) and cadmium(II) by using mixtures of primary amine N1293 and organophosphorus acids. Sep. Sci. Technol., Vol. 39, pp. 1111-1123.

Jie X.L., Liu F., Li X.Y., 2000. Effect of phosphate sorption on surface electrochemical properties of goethite and secondary sorption of zinc (In Chinese). J. Henan Agricultural University, Vol. 34, pp.109-121.

Johnson B.B., 1990. Effect of $\mathrm{pH}$, temperature, and concentration on the adsorption of cadmium on goethite. Environ. Sci.Technol., Vol.24, No.1, pp. 112-118.

Kadiravelu K., Namasivayam C., 2003. Activated carbon from coconut coir pith as metal adsorbent: adsorption of Cd(II) from aqueous solution. Adv. Environ. Res., Vol.7, pp. 471-478.

Kaikake K., Hoaki K., Sunada H., Dhakal R.P., Baba Y., 2007. Removal characteristics of metal ions using degreased coffee beans: Adsorption equilibrium of cadmium(II). Bioresour. Technol., Vol. 98, pp. 2787-2791.

Kandah M.I., 2004. Zinc and cadmium adsorption on low-grade phosphate. Sep. Puri. Technol., Vol. 35, pp. 61-70.

Karnitz Jr.O., Gurgel L.V.A., deMelo J.C.P., Botaro V.R., Melo T.M. S., Gil R.P.F., Gil L.F., 2007. Adsorption of heavy metal ion from aqueous single metal solution by chemically modified sugarcane bagasse. Bioresour. Technol., Vol. 98, pp. 1291-1297.

Karthikeyan K.G., Elliott H.A., Cannon F.S., 1996. Enhanced metal removal from wastewater by coagulant addition. Proc. 50th Purdue Industrial Waste Conf., Vol. 50, pp. 259-267.

Kocaoba S., 2007. Comparison of Amberlite IR 120 and dolamite's performance for the removal of heavy metals. J. Hazard. Mater., Vol. 147, No. 1-2, pp. 488-496.

Kocaoba S., Akcin G., 2005. Removal of chromium (III) and cadmium (II) from aqueous solutions Desalination, Vol.180, pp. 151-156.

Koivula R., Lehto J., Pajo L., Gale T., Leinonen H., 2000. Purification of metal plating rinse waters with chelating ion exchangers, Hydrometallurgy, Vol. 56, pp. 93-108.

Koukouzas N., Vasilatos C., Itskos G., Mitsis I., Moutsatsou A., 2010. Removal of heavy metals from wastewater using CFB-coal fly ash zeolitic materials. J. Hazard. Mater., Vol. 173, No. 1-3, pp. 581-588.

Krishnani K.K., Meng X., Christodoulatos C., Boddu V.M., 2008. Biosorption mechanism of nine different heavy metals onto biomatrix from rice husk. J. Hazard. Mater., Vol. 153, pp. 1222-1234.

Ku Y., Wu M-H., Shen Y-S., 2002. A study on the cadmium removal from aqueous solutions by zinc cementation. Sep. Sci. Technol., Vol. 37, No. 3, pp. 571-590.

Kula I., Uğurlu M., Karaoğlu H., Çelik A., 2008. Adsorption of Cd(II) ions from aqueous solutions using activated carbon prepared from olive stone by $\mathrm{ZnCl} 2$ activation. Bioresour. Technol., Vol. 99, No. 3, pp. 492-501.

Kumar U., Bandyopadhyay M., 2006a. Fixed bed column study for Cd(II) removal from wastewater using treated rice husk. $J$. Hazard. Mater., Vol. B129, pp. 253-259.

Kumar U., Bandyopadhyay M., 2006b. Sorption of cadmium from aqueous solutions using pretreated rice husk. Bioresour. Technol., Vol. 97, pp. 104-109.

Kumar V., Kumar M., Jha M.K, Jeong J., Jae-chun Lee J.C., 2009. Solvent extraction of cadmium from sulfate solution with di(2-ethylhexyl)phosphoric acid diluted in kerosene, Hydrometallurgy, Vol. 96, pp.230-234

Kurniawan T.A., Chan G.Y.S., Lo W.H., Babel S., 2006. Comparison of low-cost adsorbents for treating wastewater laden with heavy metals. Sci. Total Environ., Vol. 366, pp. 409-426.

Lackovic K., Angove M.J., Wells J.D., Johnson B.B., 2003. Modeling the adsorption of Cd(II) onto Muloorina illite and related clay minerals. J. Colloid Interface Sci., Vol. 257, pp. 31-40.

Lazaridis N.K., Bakoyannakis D.N., Deliyanni E.A., 2005. Chromium(VI) sorptive removal from aqueous solutions by nanocrystalline akaganeite. Chemosphere, Vol. 58, pp. 65-73.

Lee S.H., Jung C.H., Chung H., Lee M.Y., Yang J.W., 1998. Removal of heavy metals from aqueous solution by apple residues. Process Biochem., Vol. 33, No. 2, pp. 205-211.

Li X., Tang Y., Xuan Z., Liu Y., Luo F., 2007. Study on the preparation of orange peel cellulose adsorbents and biosorption of $\mathrm{Cd}^{2+}$ from aqueous solution. Sep. Puri. Technol., Vol. 55, pp. 69-75.

Li, Y. H., Wang, S., Luan, Z., Ding, J., Xu, C., Wu, D., 2003. Adsorption of cadmium(II) fromaqueous solution by surface oxidized carbon nanotubes, Carbon Vol. 41 (5), pp.1057-1062.

Lin X., Burns R.C., Lawrance G.A., 2005. Heavy metals in wastewater: the effect of electrolyte composition on the precipitation of cadmium(II) using lime and magnesia. Water, Air, \& Soil Pollution. Vol. 165, No.1-4, pp. 131-152.

Liu, Y. G., Fan, T., Zeng, G. M., Li, X., Tong, Q., Ye, F., Zhou, M., Xu, W. H., Huang, Y., 2006. Removal of cadmium and zinc ions from aqueous solution by living Aspergillus niger, Trans. Nonferr. Metal Soc. China, Vol.16, No.3, pp.681-686.Lo S. L.,

Lin C.Y., 1989. Adsorption of heavy metals from waste waters with waste activated sludge. J. Chin. Inst. Eng., Vol. 12, pp. 451461. 
Lodeiro, P., Cordero, B., Barriada, J.L., Herrero, R., Sastre de Vicente, M. E., 2005. Biosorption of cadmium by biomass of brown marine macroalgae, Bioresour. Technol. 96 (16), pp. 1796-1803.

Lodeiro P., Cordero B., Grille Z., Herrero R., Sastre de Vicente M. E., 2004. Physicochemical studies of Cd(II). Biosorption by the invasive algae in Europe. Sargassum muticum. Biotechnol. Bioeng., Vol. 88, pp.237-247.

López E., Soto B., Arias M., Nùnez A., Rubinson D., Barral M.T., 1998. Adsorbent properties of red mud and its use for wastewater treatment. Water Res. Vol. 32, pp.1314-1322.

Low K.S., Lee C.K., Liew S.C., 2000. Adsorption of cadmium and lead from aqueous solutions by spent grain. Process Biochem., Vol.36, pp. 59-64.

Lu X., Kruatrachue M., Pokethitiyook P., Homyok K., 2004. Removal of cadmium and zinc by water hyacinth, Eichhornia crassipes, Science Asia, Vol. 30, pp. 93-103.

Macías-García A., Gómez-Serrano V., Alexandre-Franco M. F., Valenzuela-Calahorro C., 2003. Adsorption of cadmium by sulphur dioxide treated activated carbon. J. Hazard. Mater., Vol.103, No. 1-2, pp. 141-152.

Mahvi A., Diels H.L., 2004. Biological removal of cadmium by Alcaligenes eutrophus CH34, Int. J. Environ. Sci. Technol., Vol.1, No.3, pp. 199-204.

Mahvi A. H., Naghipour D., Vaezi F., Nazamara S., 2005. Tea waste as an adsorbent for heavy metal removal from industrial waste waters. Am. J. Appl. Sci., Vol. 2, No.1, pp.372-375

Mahvi A., Nouri H. J., Omrani G. A., Gholami F., 2007. Application of Platanus orientalis leaves in removal of cadmium from aqueous solution, World Appl. Sci. J., Vol. 2, No.1, pp. 40-44.

Malla M.E., Alvarez M.B., Batistoni D.A., 2002. Evaluation of sorption and desorption characteristics of cadmium, lead and zinc on Amberlite IRC 718 iminodiacetate chelating ion exchanger. Talanta, Vol. 57, pp. 277-287.

Maran S.H., Protton C.F., 1971. Principles of physical chemistry, 4th edition, The Macmillan Company, New York, CollierMacmillan Ltd., London.

Marder L., Sulzbach G.O., Bernardes A.M., Ferreira J.Z., 2003. Removal of cadmium and cyanide from aqueous solutions through electrodialysis. J. Braz. Chem. Soc., Vol. 14, No.4, pp. 610-615.

Martínez M., Miralles N., Hidalgo S., Fiol N., Villaescusa I., Poch J., 2006. Removal of lead(II) and cadmium(II) from aqueous solutions using grape stalk waste. J. Hazard. Mater., Vol. B133, pp. 203-211.

Mata Y.N., Blazquez M.L., Ballester A., Gonzalez F., Munoz J.A., 2008. Characterization of biosortion of cadmium, lead and copper with the brown alga Fucus Vesiculosus. J. Hazard. Mater., Vol.158, pp.316-323.

Matheickal J.T., Iyengar L., Venkobachar C., 1991. Sorption and desorption of Cu(II) by Ganoderma lucidum. Water Poll. Res. J. Canada, Vol. 26, pp. 187-200.

Mathialagan T., Viraraghavan T., 2002. Adsorption of cadmium from aqueous solutions by perlite. J. Hazard. Mater., Vol. B94, pp. 291-303.

Mazeina L., Deore S., Navrotsky A., 2006. Energetics of bulk and nano-akaganeite, $\beta-\mathrm{FeOOH}$ : enthalpy of formation, surface enthalpy, and enthalpy of water adsorption. Chem. Mater., Vol.18, pp. 1830-1838.

Mellah A., Benachour D., 2007. The solvent extraction of zinc, cadmium and chromium from phosphoric acid solutions by tri- $n$ butyl phosphate in kerosene diluent, Sep. Purif. Technol., Vol.,56, pp. 220-224

Memon S.Q., Memon N., Shaw S.W., Khuhawar M.Y., Bhanger M.I., 2007. Saw dust-A green economical sorbent for the removal of cadmium(II) ions. J. Hazard. Mater., Vol. B139, pp. 116-121.

Min S. H., Han J. S., Shin E. W., Park J. K., 2004. Improvement of cadmium ion removal by base treatment of juniper fiber,Water Res., 38 (5) (2004) 1289-1295.

Mishra S.P., Tiwary D., 1998. Inorganic particulates in removal of toxic heavy metal ions: Efficient removal of cadmium ions from aqueous solutions by hydrous manganese oxide. Radiochimica Acta, Vol.80, No. 4, pp. 213-217.

Mitchenko T., Stender P., Makarova N., 1998. Optimization of adsorption purification of industrial effluents, waste waters and technological solutions from polyvalent metal ions. Solvent. Extr. Ion Exch., Vol.16, No.1, pp. 75-149.

Mohan S., Gandhimathi R., 2009. Removal of heavy metal ions from municipal solid waste leachate using coal fly ash as an adsorbent. J. Hazard. Mater., Vol. 169, No. 1-3, pp. 351-359.

Mohan D., Pittman Jr. C.U., Steele P.H., 2006. Single, binary and multi-component adsorption of copper and cadmium from aqueous solutions on Kraft lignin — a bioadsorbent. J. Colloid and Interface Sci., Vol. 297, pp. 489-504.

Mohan D., Singh K.P., 2002. Single-and multi component adsorption of cadmium and zinc using activated carbon derived from bagasse - an agricultural waste. Water Res., Vol. 36, pp. 2304-2318.

Mohapatra M., Anand S., 2006a. Cd(II) sorption on synthetic goethite- Kinetics and thermodynamics aspects. Indian J. Environ. Protection, Vol. 26, No. 12, pp. 1057-1066.

Mohapatra M., Anand S., 2006b. Cd(II) adsorption on OMC Chromite mine overburden, Proc. Int. Seminar on Advances In Environ. Friendly Technol. in Min. Proce. Met. Ext. AETMME-2006 held at Bhubaneswar during 1st to 3rd Nov., 2006. ISBN 81-902502-3-X. pp. 35-49.

Mohapatra M., Anand S., 2007a. Studies on sorption of Cd(II) on Tata chromite mine overburden, J. Hazard. Mater., Vol. 148, No.3, pp. 553-559. 
Mohapatra M., Anand S., 2007b. Cd(II) adsorption on high iron containing lateritic ore of Orissa. Indian J. Environ. Protection, Vol.27, No.6, pp.509-515.

Mohapatra M., Khatun S., Anand S., 2008. Adsorption of heavy metal ions on manganese nodule - A Comparative study. Pollution Res., Vol.25, No.3, pp.563-568.

Mohapatra M., Rout K., Anand S. 2009a. Synthesis of Mg(II) doped goethite and its cation sorption behaviour. J. Hazard. Mater., Vol. 171, No.1-3, pp.417-423.

Mohapatra M., Rout K., Mohapatra B.K., Anand S., 2009b. Sorption behavior of Pb(II) and Cd(II) on iron ore slime and characterization of metal ion loaded sorbent. J. Hazard. Mater., Vol.166, pp.1506-1513.

Mohapatra M., Khatun S., Anand S., 2009c. Adsorption behaviour of Pb(II), Cd(II) and Zn(II) on Nalco Plant Sand. Indian J. Chem. Technol. Vol. 16, pp. 291-300.

Mohapatra M., Padhi T., Dash T., Singh P., Anand S., Mishra B.K., 2010a. Synthesis of 6-line nano structured ferrihydrite and its cation adsorption behaviour. Paper communicated to Toxicology and Environmental Chemistry.

Mohapatra M., Mohapatra L., Satpati B., Anand S., Mishra B.K., 2010b. In-situ one pot synthesis of high surface area nano akaganeite powder and its cation sorption behaviour. Journal of Chemical and Engineering Data. Vol. 55, pp.1486-1491.

Montanher S.F., Oliveira E.A., Rollemberg M.C., 2005. Removal of metal ions from aqueous solutions by sorption onto rice bran. J. Hazard. Mater., Vol. B 117, pp. 207-211.

Mortaheb R.H., Kosuge H., Mokhtarani B., Amini M.H., Banihashemi H.R., 2009. Study on removal of cadmium from wastewater by emulsion liquid membrane. J. Hazard. Mater., Vol. 165, pp. 630-636.

Mustafa G., Singh B., Kookana R.S., 2004. Cadmium sorption and desorption behaviour on goethite at low equilibrium concentrations: effects of $\mathrm{pH}$ and index cations. Chemosphere, Vol. 57, pp. 1325-1333.

Nadeem M., Shabbir M., Abdullah M.A., Shah S.S., McKay G., 2009. Sorption of cadmium from aqueous solution by surfactantmodified carbon adsorbents. Chem. Eng. J., Vol. 148, No. 2-3, pp. 365-370.

Naiya T.K., Chowdhury P., Bhattacharya A.K., Das S.K., 2009. Saw dust and neem bark as low-cost natural biosorbent for adsorptive removal of $\mathrm{Zn}(\mathrm{II})$ and $\mathrm{Cd}(\mathrm{II})$ ions from aqueous solutions. Chem. Eng. J., Vol. 148, pp. 68-79.

Namasivayam C., Ranganathan K., 1995. Removal of Cd(II) from waste water by adsorption on waste Fe(III)/Cr(III) hydroxide. Water Res., Vol. 29, pp. 1737-1744.

Nogueira C.A., Delmas F., 1999. New flow sheet for the recovery of cadmium, cobalt, and nickel from spent Ni-Co batteries by solvent extraction. Hydrometallurgy, Vol. 52, pp. 267-287.

Nouri L., Ghodbane I., Hamdaoui O., Chiha M., 2007. Batch sorption dynamics and equilibrium for removal of cadmium ions from aqueous phase using wheat bran. J. Hazard. Mater., Vol.149, pp. 115-125.

O'reilly S.E., Hochella Jr. M.F., 2003. Lead sorption efficiencies of natural and synthetic Mn and Fe-oxides. Geochim. Cosmochim. Acta. Vol. 67, pp. 4471-4487.

Oh Sanghwa, Kwak Moon Yong, Shin Won Sik, 2009. Competitive sorption of lead and cadmium onto sediments. Chem.Eng. J., Vol. 152, No. 2-3, pp. 376-388.

Orhan Y., Bujukgungor H., 1993. The removal of heavy metals by using agricultural wastes. Water Sci. Technol., Vol. 28, No.2, pp. 247-255.

Oshima, S., Perera, J. M., Northcott, K. A., Kokusen, H., Stevens, G. W., Komatsu, Y., 2006. Adsorption behavior of cadmium(II) and lead(II) on mesoporous silicateMCM-41. Sep. Sci. Technol., Vol.41 No.8, pp.1635-1643.

Ozer A., Pirincci H.B., 2006. The adsorption of Cd(II) ions on sulphuric acid-treated wheat bran. J. Hazard. Mater., Vol. B137, pp. 849-855.

Panda G.C., Das S.K., Chatterjee S., Maity P.B., Bandopadhyay T.S., Guha A.K., 2006. Adsorption of cadmium on husk of Lathyrus sativus: Physico-chemical study. Colloids and Surfaces B: Biointerfaces, Vol. 50, pp. 49-54.

Pandey P.K., Verma Y., Choubey S., Pandey M., Chandrasekhar K., 2008. Biosorptive removal of cadmium from contaminated groundwater and industrial effluents, Bioresour. Technol., Vol. 99, pp. 4420-4427.

Pang, L., Close, M., Greenfield, H., Stanton, G., 2004. Adsorption and transport of cadmium and rhodamine WT in pumice sand columns. New Zealand J. Mar.Freshwater Res., Vol. 38, 367-378.

Papandreou A., Stournaras C.J., Panias D., 2007. Copper and cadmium adsorption on pellets made from fired coal fly ash. J. Hazard. Mater., Vol. 148, No. 3, pp. 538-547.

Park S.J., Jang Y.S., 2002. Pore structure and surface properties of chemically modified activated carbons for adsorption mechanisms and rate of Cr(VI). J. Colloid Interf. Sci., Vol. 249, pp. 458-463.

Park S.J., Kim K.D., 1999. Adsorption behaviour of $\mathrm{CO}_{2}$ and $\mathrm{NH}_{3}$ on chemically surface treated activated carbons. J. Colloid. Interf. Sci., Vol. 212, pp. 458-463.

Pehlivan E., Altun T., 2006. The study of various parameters affecting the ion exchange of $\mathrm{Cu}^{2+}, \mathrm{Zn}^{2+}, \mathrm{Ni}^{2+}, \mathrm{Cd}^{2+}$, and $\mathrm{Pb}^{2+}$ from aqueous solution on Dowex $50 \mathrm{~W}$ synthetic resin. J. Hazard. Mater., Vol. B134, pp. 149-156.

Pehlivan E., Yanik B.H., Ahmetli G., Pehlivan M., 2008. Equilibrium isotherm studies for the uptake of cadmium and lead ions onto sugar beet pulp. Bioresour. Technol., Vol. 99, pp. 3520-3527.

Petersen W., Wallmann K., Schröer S., Schroeder F., 1993. Studies on the adsorption of cadmium on hydrous iron(III) oxides in oxic sediments. Analytica Chimica Acta, Vol. 273, No.1-2, pp. 323-327. 
Pino G.H., de Mesquita L.M.S., Torem M.M.L., Pinto G.A.S., 2006. Biosorption of cadmium by green coconut shell powder, Miner. Eng., Vol. 19, pp. 380-387.

Pradhan B.K., Sandle N.K., 1999. Effect of different oxidizing agent treatments on the surface properties of activated carbons. Carbon, Vol. 37, pp. 1323-1332.

Preston J.S., Patrick J.H., Steinbach G., 1994. The selective solvent extraction of cadmium by mixtures of carboxylic acids and trialkylphosphine sulphides. Part 2. Practical applications in the separation of cadmium from zinc and nickel. Hydrometallurgy, Vol. 36, No. 2, pp. 141-158.

Puls R.W., Bohn H.L., 1988. Sorption of cadmium, nickel, and zinc by kaolinite and montmorillonite. Soil Sci. Soc. Am. J., Vol. 52, pp. 1289-1292.

Qaiser S., Saleemi A.R., Ahmad M.M., 2007. Heavy metal uptake by agro based waste materials. Environ. Biotechnol., Vol.10, pp. 409-416.

Rangel, J. I. D., Solache-Rios, M., Badillo-Almaraz, V. E., 2006. Comparison of three Mexican aluminosilicates for the sorption of cadmium. J. Radioanal. Nucl.Chem. 267 (1), pp.139-145.

Rangel-Mendez J.R., Tai M.H., Streat M., 2000. Removal of cadmium using electrochemically oxidized activated carbon. Process Safety and Environ. Protection, Vol. 78, No.2, pp.143-148.

Ramos R.L, Jacome L.A.B., Rodriguez I.A., 2005. Adsorption of cadmium(II) from aqueous solution on natural and oxidized corncob. Sep. Puri. Technol., Vol. 4, pp. 41-49.

Rao K.S., Anand S., Venkateswarlu P., 2010a. Adsorption of cadmium (II) ions from aqueous solutions by Tectona Grandis L.F. (Teak leaves powder). Bioresources, Vol. 5, No.1, pp.438-454.

Rao K.S., Anand S., Venkateswarlu P., 2010b. Psidium guvajava $l$ leaf powder - A potential low cost biosorbent for the removal of cadmium(II) from wastewater. Adsorption Science and Technology, Vol. 28, No. 2, pp. 163-178.

Rao K.S., Anand S., Venkateswarlu P., 2010c. Equilibrium and kinetic studies for Cd(II) adsorption from aqueous solution on Terminalia Catappa Linn leaf powder biosorbent. Paper in press in Indian J. Chem. Technol.

Rao K.S., Anand S., Venkateswarlu P., 2010d. Kinetic, isothermic and thermodynamic studies for Cd(II) adsorption from aqueous solution on Ficus Religiosa leaf powder and characterization of loaded biosorbent. Paper accepted in Clean: Soil, Air and Water.

Rao K.S., Anand S., Venkateswarlu P., 2010e. Cadmium adsorption from aqueous solution with agricultural waste biosorbent Syzygium cumini L leaf powder: Equilibrium and kinetic studies. Korean J. Chem. Eng., DOI: 10.1007/s11814-010-0243-2.

Rao K.S., Anand S., Venkateswarlu P., 2010f. Modeling of kinetics of Cd(II) sorption on Syzygium cumini L leaf powder in a fixed bed mini column. Paper accepted in J. Indus. Engg. Chem.

Rao M. M., Ramesh A., Rao G.P.C., Seshaiah K., 2006. Removal of copper and cadmium from the aqueous solutions by activated carbon derived from Ceiba pentandra hulls. J. Hazard. Mater., Vol. B129, pp. 123-129.

Reddy B.R., Priya D.N., Park K.H., 2006. Separation and recovery of cadmium(II), cobalt(II) and nickel(II) from sulphate leach liquors of spent Ni-Cd batteries using phosphorus based extractants. Sep. Puri. Technol., Vol.50, No.2, pp.161-166.

Reddy M.L.P., Preetha G.P., Meena C.V., Rao T.P., Iyer C.S.P., Damodaran A.D., 1996. The separation of zinc(II) and cadmium(II) by liquid-liquid extraction. J. Radioanalytical and Nucl. Chem., Vol. 211, No.2, pp. 305-316.

Reddy Y.S.K., Graybill D., vonWandruszka R., 2009. Adsorbents for the removal of arsenic, cadmium, and lead from contaminated waters. J. Hazard. Mater., Vol. 171, No.1-3, pp. 1-15.

Rickelton W.A., 1998. The removal of cadmium impurities from cobalt-nickel solutions by precipitation with sodium diisobutyldithiophosphinate. Hydrometallurgy. Vol. 50, No. 3, pp. 339-344.

Ricordel S., Taha S., Cisse I., Dorange G., 2001. Heavy metals removal by adsorption onto peanut husks carbon: characterization, kinetic study and modeling. Sep. Puri. Technol., Vol. 24, pp. 389-401.

Rout K., Mohapatra M., Anand S., 2009a. Lead, cadmium and zinc adsorption on Low Grade Bauxite Ore. Indian J. Environ. Protection, Vol. 29, No.1, pp. 30-35.

Rout K., Mohapatra M., Mohapatra, B. K., Anand S., 2009b. Pb(II), Cd(II) and Zn(II) adsorption on low grade manganese ore. International Journal of Engineering, Science and Technology, Vol. 1, No. 1, pp. 106-122.

Saeed A., Akhter M. W., Iqbal M., 2005. Removal and recovery of heavy metals from aqueous solution using papaya wood as a new biosorbents. Sep. Puri. Technol., Vol. 45, pp. 25-31.

Saeed A., Iqbal M., 2003. Bioremoval of cadmium from aqueous solution by black gram husk (Cicer arientinum). Water Res., Vol.37, pp. 3472-3480.

Salim R., Al-Subu M. M., Sahrhage E., 1992. Uptake of cadmium from water by beech leaves. J. Environ. Sci. Health., Vol. A27, No. 3, pp. 603- 627.

Sar1 A., Tuzen M., 2008. Biosorption of cadmium(II) from aqueous solution by red algae (Ceramium virgatum): Equilibrium, kinetic and thermodynamic studies. J. Hazard. Mater., Vol.157, pp. 448-454.

Sarkanen K.V., Ludwig C.H., 1971. Lignins-Occurance, Formation, Structure and Reactions. Wiley-Interscience, New York, 1971.

Schindler P.W., Leichti P., Westall J.C., 1987. Adsorption of copper, cadmium and lead from aqueous solution to the kaolinite/water interface. Neth. J. Agric. Sci., Vol. 35, pp. 219-230. 
Schlage Lock Company (San Francisco, CA), 1975. Removal of heavy metal ions from plating wastes. United States Patent, 3869386.

Schwertmann U., 1988. In Iron in Soils and Clay Minerals, ed. By J.W. Stucki, B.A. Goodman, U. Schwertmann, NATO ASI Ser. 217, pp. 267.

Schwertmann U., Cornell R.M., 1991. In: The Iron Oxides: Preparation and Characterization, Ed , Brenzinger, C.D, publisher pp. 64.

Schwertmann U., Taylor R.M., 1977. In Minerals in Soil Environments; Dixon, J. B., Weed, S. B., Eds.; Soil Sci. Soc. Am. Madison, WI, 145.

Sciban M., Klasnja M., Skrbic B., 2006. Modified hardwood sawdust as adsorbent of heavy metal ions from water. Wood Sci. Technol., Vol. 40, pp. 217-227.

Sciban M., Radetic B., Kevresan Z., Klasnja M., 2007.Adsorption of heavy metals from electroplating waste water by wood saw dust. Bioresour. Technol., Vol. 98, pp. 402-409.

Scott J.A., Palmer S.J., 1990. Sites of cadmium uptake in bacteria used for biosorption. Appl. Microbiol. Biotechnol., Vol. 33, pp. 221-225.

Seki K., Saito N., Aoyama M., 1997. Removal of heavy metal ions from solutions by coniferous barks. Wood Sci. Technol., Vol. 31, pp. 441-447.

Sen T.K., Sarzali M.V., 2008. Removal of cadmium metal ion $(\mathrm{Cd} 2+)$ from its aqueous solution by aluminium oxide $\left(\mathrm{Al}_{2} \mathrm{O}_{3}\right)$ : $\mathrm{A}$ kinetic and equilibrium study. Chem. Eng. J., Vol. 142, pp.256-262.

Sen T.K., Mahajan S.P., Khilar K.C., 2002. Sorption of $\mathrm{Cu}^{2+}$ and $\mathrm{Ni}^{2+}$ on iron oxide and kaolin and its importance on $\mathrm{Ni}^{2+}$ transport in porous media. Colloids Surfaces A: Physicochem. Eng. Aspects, Vol. 211, pp.91-102.

Sharma A., Bhattacharyya K.G., 2005. Azadirachta indica (Neem) leaf powder as a biosorbent for removal of Cd(II) from aqueous medium. J. Hazard. Mater., Vol. B125, pp. 102-112.

Shen J. Duvnjak Z., 2005. Adsorption kinetics of cupric and cadmium ions on corncob particles. Process Biochem., Vol. 40, pp. 3446-3454.

Sherif Y. E., Ashmawy A., Badr S., 2008. Biosorption of cadmium and nickel by Nilewater algae, J. Appl. Sci. Res., Vol. 4, No. 4, pp. 391-396.

Singh K.K., Rastogi R., Hasan S.H., 2005. Removal of cadmium from wastewater using agricultural waste 'rice polish'. J. Hazard. Mater., Vol. A121, pp. 51-58.

Singh K.K., Singh A.K., Hasan S.H., 2006. Low cost bio-adsorbent 'wheat bran' for the removal of cadmium from wastewater: Kinetic and equilibrium studies. Bioresour. Technol., Vol. 97, pp. 994-1001.

Srivastava S.K., Bhattacharjee G., Tyagi R., Pant N., Pal N., 1988. Studies of the removal of some toxic metal ions from aqueous solutions and industrial waste. Part I (removal of lead and cadmium by hydrous iron and aluminium oxide. Environ. Technol . Lett., Vol. 9, pp. 1173-1185.

Sud D., Mahajan G., Kaur M.P., 2008. Agricultural waste material as potential adsorbent for sequestering heavy metal ions from aqueous solutions - A review. Bioresour. Technol., Vol.99, pp. 6017-6027.

Sun G., Shi W., 1998. Sunflower stalks as adsorbents for the removal of metal ions from wastewater. Ind. Eng. Chem. Res., Vol. 37, pp. 1324-1328.

Suraj G., Iyer C.S.P., Lalithambika M., 1998. Adsorption of cadmium and copper by modified kaolinites. Applied Clay Sci., Vol. 13, No. 4, pp. 293-306.

Swain B., Sarangi K., Das R.P., 2006. Effect of different anions on separation of cadmium and zinc by supported liquid membrane using TOPS-99 as mobile carrier. J. Membrane Sci., Vol. 277, No.1-2, pp. 240-248.

Takeshita K., Watanabe K., Nakano Y., Watanabe M., 2003. Solvent extraction separation of Cd(II) and $\mathrm{Zn}$ (II) with the organophosphorus extractant D2EHPA and the aqueous nitrogen-donor ligand TPEN. Hydrometallurgy, Vol. 70, pp. 63-71.

Taha A.A., Ghani, S.A.H.A.E., 2004. Effect of surfactants on the cementation of cadmium, J. Colloid and Interface Sci., Vol. 280, pp. 9-17.

Takeshita K., Watanabe K., Nakano Y., Watanabe M., 2004. Extraction separation of Cd(II) and Zn(II) with Cyanex 301 and aqueous nitrogen-donor ligand TPEN. Solvent Extr. Ion Exch., Vol. 22, pp. 203-218.

Tan G., Xiao D., 2009. Adsorption of cadmium ion from aqueous solution by ground wheat stems. J. Hazard. Mater., Vol. 164, pp. 1359-1363.

Tarley C.R.T., Arruda M.A.Z., 2004. Biosorption of heavy metals using rice milling byproducts. Characterization and application for removal of metals from aqueous effluents. Chemosphere, Vol. 54, pp. 987-995.

Tee T.W., Khan R.M., 1988. Removal of lead, cadmium and zinc by waste tea leaves. Environ. Technol. Lett., Vol. 9, pp. 12231232.

Toles C.A., Marshall W.E., Johns M.M., 1999. Surface functional groups on acid activated nutshells carbon. Carbon, Vol. 37, pp. 1207-1214.

Tonkin J.W., Balistrieri L.S., Murray J.W., 2004. Modeling sorption of divalent metal cations on hydrous manganese oxide using the diffuse double layer model. Applied Geochemistry, Vol. 19, No. 1, pp. 29-53. 
Touati M., Zayani M.B., Ariguib N.K., Ayadi M.T., Buch A., Grossiord J.L., Pareau D., Stambouli M., 2009. Solvent extraction of cadmium from sulfate solution with di-(2-ethylhexyl)phosphoric acid diluted in kerosene, Hydrometallurgy, Vol. 95, pp.135140

Tripathy S. S., Bersillon J.L., Gopal K., 2006. Adsorption of $\mathrm{Cd}^{2+}$ on hydrous manganese dioxide from aqueous solutions. Desalination, Vol. 194, No. 1-3, pp. 11-21.

Urtiaga A.M., Alonso A., Ortiz I., Daoud J.A., El-Reefy S.A., Pérez de Ortiz S., Gallego T., 2000. Comparison of liquid membrane processes for the removal of cadmium from wet phosphoric acid. J. Membrane Sci., Vol. 164, No. 1-2, pp. $229-240$.

Vaclavikova, M., Gallios, G. P., 2006. Removal of cadmium, zinc, lead and copper biosorption on leaching residue from nickel production. Acta Montanistica Slovaca, Vol. 11, pp. 393-396.

Vaclavikova M., Misaelides P., Gallios G., Jakabsky S., Hredzak S., 2005. Removal of cadmium, zinc, copper and lead by red mud, an iron oxides containing hydrometallurgical waste. Stud. Surf. Sci. Catal. Vol. 155, pp. 517-525.

Vasudevan, P., Padmavathy, V., Dhingra, S. C., 2003. Kinetics of biosorption of cadmium on baker's yeast, Bioresour. Technol., Vol.89 (3), pp. 281-287.

Vázquez G., Antorrena J., González M.D., Doval M.D., 1994. Adsorption of heavy metal ions by chemically modified pinus pinaster bark. Bioresour. Technol., Vol. 48, pp. 251-255.

Venema P., Hiemstra T., Riemsdijk W.H., 1997. Multisite interaction of cadmium with phosphate on goethite. J. Colloid Interf. Sci. Vol. 192, No.1, pp. 94-103.

Venema P., Hiemstra T., Weidler P.G., Riemsdijk W.H.V., 1998. Intrinsic proton affinity of reactive surface groups of metal (hydr)oxides: Application to iron (hydr)oxides. J. Colloid Inter Sci, Vol.198, pp. 282-295.

Vieira R.H.S.F., Volesky B., 2000. Biosorption: a solution to pollution. Int. Microbiol., Vol. 3, pp. 17-24.

Volesky B., 1990. Biosorption and biosorbents. In:Biosorption of Heavy Metals, ed. B. Volesky. CRC Press Inc., Boca Raton.

Volesky B., Holan Z.R., 1995. Biosorption of heavy metals. Biotechnol. Prog., Vol. 11, pp. 235-250.

Volesky B., May H., Holan Z., 1993. Cadmium bio-sorption by S. cerevisiae. Biotechnol. Bioeng., Vol. 41, pp. 826-829.

Wang K.J., Xing W., 2002. Sorption and desorption of cadmium by goethite pretreated with phosphate. Chemosphere, Vol. 48, pp. 665-670.

Wang W., Fthenakis W., 2005. Kinetics study of cadmium from tellurium in acidic solution media using ion-exchange resins. $J$. Hazard. Mater., Vol. B125, pp. 80-88.

Warren L.A., Outridge P. M., Zimmerman A.P., 1995. Geochemical partitioning and bioavalability of copper to aquatic plants in an artificial oxide-organic sediment. Hydrobiologia, Vol. 304, pp. 97-207,

Williams C.J., Aderhold D., Edyvean R.G.J., 1998. Comparison between biosorbents for the removal of metal ions from aqueous solutions. Water Res., Vol. 32, pp. 216-224.

Wu J., Lu J., Chen T.H., He Z., Su Y.,Yao X. Y., 2010. In situ biotreatment of acidic mine drainage using straw as sole substrate. Environ. Earth Sci., Vol 60: pp. 421-429.

Xue Y., Hou H., Zhu S., 2009. Competitive adsorption of copper(II), cadmium(II), lead(II) and zinc(II) onto basic oxygen furnace slag. J.Hazard. Mater., Vol. 162, No.1, pp. 391-401.

Yavuz, O., Guzel, R., Aydin,F., Tegin, I., Ziyadanogullari, R., 2007.Removal of cadmium and lead fromaqueous solution by calcite, Polish J. Environ. Stud., Vol.16 (3), pp. 467-471.

Younesi S.R., Alimadadi H., Alamdari E.K., Marashi S.P.H., 2006. Kinetic mechanisms of cementation of cadmium ions by zinc powder from sulphate solutions. Hydrometallurgy, Vol. 84, pp. 155-164.

Yu G., Saha U.K., Kozak L.M., Huang P.M., 2006. Kinetics of cadmium adsorption on aluminum precipitation products formed under the influence of tannate. Geochimica et Cosmochimica Acta, Vol. 70, No. 20, pp. 5134-5145.

Zacaria, R., Gerente,C., Andres, Y., Cloirec, P. L., 2002. Adsorption of several metal ions onto low-cost biosorbent: kinetic and equilibrium studies. Environ. Sci.Technol.,Vol.36 (2002) 2067-2073.

Zadrozna, M. K., Klimiuk, E., Baryla, I. W., 2004. Cyclical cadmium adsorption and desorption by activated sludge immobilized on alginate carriers, Polish J. Environ. Stud., Vol.13 No.2, pp. 161-169.

Zaman M.I., Mustafa S., Khan S., Xing B., 2009. Effect of phosphate complexation on $\mathrm{Cd}^{2+}$ sorption by manganese dioxide $(\beta-$ $\mathrm{MnO}_{2}$ ). J. Colloid Interf. Sci., Vol. 330, No.1, pp. 9-19.

Zhang G.Y., Dong Y.Y., Li X.Y., 2001. Effects and mechanisms of oxalate on Cd(II) sorption on goethite at different $\mathrm{pH}$ and electrolyte concentration (In Chinese). Plant Nutrition and Fertilizer Science, Vol. 7, pp. 305-310.

Zheng W., Li X.M, Wang F., Yanga Q., Dengb P., Zenga G.M., 2008. Adsorption removal of cadmium and copper from aqueous solution by areca-A food waste. J. Hazard. Mater., Vol.157, pp. 490-495.

Zhu C., Luan Z., Wang Y., Shan X., 2007. Removal of cadmium from aqueous solutions by adsorption on granular red mud (GRM). Separ. Purif. Technol., Vol.57, pp. 161-169.

\section{Biographical notes}

K.S. Rao did his M. Tech (Chem.Eng) from Kakatiya University,Warangal, India. He is senior scientist at Hydro-Electro Metallurgy Department of Institute of Minerals and Materials Technology, Bhubaneswar, India. He has worked extensively in the areas of solvent extraction, ion exchange, adsorption and bioleaching. He has expertise in designing, commissioning of hydrometallurgical pilot and commercial plants. 
M. Mohapatra holds Ph.D. from Utkal University. She is scientist at Hydro-Electro Metallurgy Department of Institute of Minerals and Materials Technology, Bhubaneswar, India. She has developed expertise in synthesis of various iron phases of iron oxides/hydroxides using variety of techniques which include chemical precipitation, surfactant mediation, hydrothermal and micro-emulsion. Her fields of interest are: hydrometallurgy, synthesis of nano materials which include iron, cerium, titanium oxides and barium titanates.

S. Anand obtained her Ph.D degree from Indian Institute of Technology, Delhi. She is presently Adjunct Professor, Faculty of Minerals and Energy, Murdoch University, Western Australia since May 2009. She had worked at Institute of Minerals and Materials Technology, India, for thirty two years in different positions and superannuated in December 2008. Her areas of interest are: hydrometallurgy, high pressure leaching, Nano material synthesis and their application, mitigation of toxic ions from aqueous solution by adsorption technique.

P. Venkateswarlu holds Ph.D degree in Chemical Engineering from Andhra University, India. He has 32 years of teaching experience. He has developed expertise in the area of fluidization and mass transfer. At present, he is the chairman, board of Studies in Chemical Engineering. His current research interest is application of biosorption technique for the removal of toxic heavy metal ions from industrial wastewaters.

Received 2010

Accepted 2010

Final acceptance in revised form 2010 